International Journal of Science and Education, 4(2), 85-110

Uluslararası Bilim ve Eğitim Dergisi, 4(2), 85-110

DOI: 10.47477/ubed.952556

Makale Türü: Araştırma Makalesi

Başvuru Tarihi: 14.06.2021

Yayına Kabul Tarihi: 28.08.2021

\title{
Proje Tabanlı Öğrenme ile Kazanılan 21. Yüzyıl Becerilerine Yönelik Bir Nitel Araştırma*
}

\author{
Ömer UYSAL ${ }^{1}$
}

Öz

Proje tabanlı öğrenme (PTÖ); problem çözmeye, eleştirel düşünmeye, işbirliğine, iletişime ve yenilik üretmeye oldukça uygun bir zemindir. Bu yönüyle PTÖ, 21. Yüzyıl becerilerinin kazandırılması için kullanılabilecek bir yöntem olarak düşünülebilir. Araştırmanın amacı, araştırma sonuçları doğrultusunda PTÖ ile kazanılabilen 21. Yüzyıl becerilerini belirleyebilmektir. Araştırma nitel olarak desenlenmiş bir doküman incelemesidir. Verilerin analiz edilebilmesi için nitel betimsel analiz tekniği kullanılmıştır. Araştırmada, bulgularında 21. Yüzyıl beceri kazanımına ilişkin sonuç üretmiş olan PTÖ araştırmaları değerlendirmeye alınmıştır. Araştırma kapsamında toplam 168 akademik yayın üzerinde çalışılmıştır. Araştırma sonuçları göstermektedir ki 21 Yüzyıl becerileri kazanımına yönelik PTÖ araştırmalarında en çok akademik başarı, tutum geliştirme, motivasyon, kalıcılık, işbirliği, problem çözme, yenilik ve düşünme becerileri çalışılmıştır. Araştırma bulgularına toplu olarak bakıldığında PTÖ araştırmalarının en sık olarak iletişim, işbirliği, araştırma, akademik başarı, üretkenlikverimlilik, yenilik-yaratıcılık, motivasyon, düşünme becerileri, sorumluluk, problem çözme ve tutum geliştirme becerileri kazandırdığ 1 ifade edilebilir.

Anahtar Kelimeler: 21. yüzyıl becerileri, proje tabanlı öğrenme, beceri kazanımı, nitel araştırma.

\section{A Qualitative Research on 21st Century Skills Acquired by Project Based Learning}

\begin{abstract}
Project based learning (PBL) provides a basis for problem solving, critical thinking, collaboration, communication and innovation. With this aspect, PBL can be thought as a method using to achieve 21st century skills. The research aims to identify 21st century skills achieved by PBL in the direction of results of dissertations and papers. The research designed by qualitative method is a document analysis. Qualitative descriptive analysis was used to data analysis. The dissertations and papers were collected considering finding section including 21st century skills achieved by PBL. 168 scientific researches were analyzed and reviewed in the scope of this research. The results of the research show that academic achievement, attitude development, motivation, persistence, cooperation, problem solving, innovation and thinking skills are mostly studied in PBL research for 21st Century skills acquisition. According to finding of the research, communication, collaboration, research, information literacy, academic success, productivity, innovation-creativity, motivation, thinking skills, responsibility, problem solving and attitude improvement are the most frequent 21st century skills acquired by PBL.
\end{abstract}

Key Words: 21st century skills, project based learning, skill achievement, qualitative research.

\footnotetext{
*Bu araştırma, 5-7 Aralık 2018 tarihlerinde İstanbul Üniversitesinde düzenlenen Uluslararası Yükseköğretimde Kalite Kongresi'nde sadece Türkçe özet olarak basılan çalışmanın geliştirilmiş tam metnidir.
}

1Corresponding Author: Dr., Türkiye, uysalomer@gmail.com, ORCID: 0000-0003-4351-1954 


\section{Giriş}

Eğitim kurumları ve öğrenme merkezleri öğrencilere çağın ihtiyaçlarına uygun bilgi beceri ve tutum kazandırmaya çalışmaktadır. Alan uzmanları bilgi toplumunun özelliklerini ve ideallerini dikkate alarak birtakım beceriler belirlemiştir. Bu beceriler 21. Yüzyıl becerileri olarak ifade edilmektedir. Alanyazında 21. Yüzyıl becerilerine yönelik olarak farklı sinıflamalar yer almaktadır (Altınpulluk ve Yıldırım, 2021; Anagün vd., 2016, 162; Ananiadou ve Claro, 2009; Binkley vd., 2012; Dağhan vd., 2017; Ekici vd., 2017; Kalemkuş ve Bulut Özek, 2021; P21, 2009).

21. Yüzyıl becerilerinin öğrencilere kazandırılabilmesi için çeşitli yöntem ve teknikler aranmaktadır. Proje tabanlı öğrenme (PTÖ); öğrenme sürecinin yapılandırılmasına bağlı olarak problem tabanlı öğrenme, aktif öğrenme, sosyal öğrenme, takım halinde öğrenme ve buluş yoluyla öğrenme gibi etkili öğrenme yöntemlerini aynı anda çalıştırabilmektedir. Korkmaz ve Kaptan da (2001) PTÖ yaklaşımının diğer öğretim yöntem ve teknikleriyle birlikte kullanılabilen çok yönlü bir yaklaşım olduğunu belirtmektedir. PTÖ, gerçek hayatı tanıma, hayata hazırlanma, hayat içinde karşılaşılan sorunlara çözüm bulma anlamında uzmanlar tarafından özellikle tavsiye edilmektedir (Bell, 2010; Blumenfeld vd., 1991; ETDME, 2006; Talat ve Chaudhry, 2014; Trilling ve Fadel, 2009; Uysal, 2016).

Buck Eğitim Enstitüsü, “Neden tüm dünyada birçok eğitmen, öğretici PTÖ ile bu kadar ilgilidir?" sorusunu PTÖ'nün üniversite, kariyer ve sivil hayattaki başarı becerilerini oluşturduğunu ifade ederek yanıtlanmaktadır (Hallermann, vd., 2011). 21.yy. çalışma alanında ve üniversitelerde başarılı olmak için artık temel bilgi ve becerilerden daha fazlası gerekmektedir. Bir projede öğrenciler girişken olmayı, sorumluluk almayı, eleştirel düşünmeyi, özgüven oluşturmayı, problem çözmeyi, bir ekiple beraber çalışmayı, fikirlerini ifade etmeyi kendilerini daha etkili bir şekilde yönetebilmeyi öğrenebilmektedir (Asan ve Haliloğlu, 2005; Asilsoy, 2007; Avcı vd., 2016; Avşar, 2017; Ay, 2013; Başbay, 2006; Benzer, 2010; Thomas, 2000). PTÖ'nün altın standartları olarak ele alınan "Anahtar Bilgiler, Anlama ve Başarı Becerileri" proje tasarım ilkesi de bu becerilere atıf yapmaktadır (Larmer, Mergendoller ve Boss, 2015). Bu yönüyle PTÖ, 21. Yüzyıl becerilerinin kazandırılması için kullanılabilecek bir yöntem olarak düşünülebilir (Demiral, 2015, Lin vd., 2015; Moylan, 2008; Wurdinger ve Qureshi, 2015).

Alanyazının önemli konulardan olan PTÖ ve 21. Yüzyıl becerilerine yönelik yoğun araştırmalar yapılmaktadır. PTÖ’ye yönelik yaygın olarak akademik başarı, tutum geliştirme, motivasyon, kalıcılık, işbirliği, problem çözme, yenilik ve düşünme becerilerine yönelik araştırmalar yürütülmektedir (Acar, 2011; Aldemir, 2013; Asan ve Haliloğlu, 2005; Baş, 2011; Başer, Özden ve Karaarslan, 2017; Birinci, 2008; Çıbık, 2006; Çiftçi, 2006; Işık, 2007; Keskin, 2011). 21. Yüzyıl becerilerine yönelik yaygın olarak 21. Yüzyıl becerilerinin belirlenmesi ve tanımlanması, 21. Yüzyıl becerileri ölçeği geliştirilmesi, hedef kitlenin 21. Yüzyıl becerileri açısından değerlendirilmesi, 21. Yüzyıl becerilerine yönelik araştırmaların toplu bir şekilde incelenmesine yönelik araştırmalar gerçekleştirilmektedir (Altınpulluk ve Yıldırım, 2021; Anagün vd., 2016; Binkley vd., 2012; Dede, 2010; Ekici vd., 2017; Kalemkuş ve Bulut Özek, 2021; Kıyasoğlu ve Çeviker Ay, 2020; Şahin, 2010).

21. yüzyıl becerileri hedef kitleye nasıl kazandırılabilir? sorusu eğitim ve öğrenme adına oldukça yerinde, anlamlı ve değerli bir sorudur. Bu sorunun etkili bir şekilde yanıtlanabilmesi için kurumlar ve uzmanlar tarafından ciddi araştırmalar yapılmaktadır. Eğitim ve ders programları, öğrenme/öğretim yöntemleri ve etkinlikler 21. Yüzyıl becerileri dikkate alınarak hazırlanmaktadır. Günümüzde gerek yurt dışında gerekse ülkemizde eğitim kurumlarında PTÖ yöntemi tercih edilmekte ve hatta proje okulları açılmaktadır. Alanyazında PTÖ ile 21. Yüzyıl becerilerinin kazanımına yönelik araştırmalar da yer almaktadır. Bu araştırmalarda 21. Yüzyıl becerilerinin geliştirilmesi için PTÖ yöntemi kullanımı, Takım halinde PTÖ uygulamaları ile 21. Yüzyıl becerilerinin geliştirilmesi, PTÖ ve 21. Yüzyıl becerilerinin öğrencilerin yenilikçilik ve yarışmacılıklarına etkisi, 21. Yüzyıl iş ortamlarında 
PTÖ, 21. Yüzyıl becerilerinin kazanımında PTÖ'nün etkililiğinin incelenmesi ve PTÖ ile 21. Yüzyıl becerilerinin gelişimine yönelik öğrenci algılarına yönelik konular üzerinde durulduğu görülmektedir (Bell, 2000; Fatmawati, 2018; Lin vd., 2015; Moylan, 2008; Musa vd., 2011; Ravitz vd., 2012; Talat ve Chaudhry, 2014).

Öğrenciler PTÖ sayesinde içerik bilgisini daha kalıcı olarak anlamakla birlikte, 21 Yüzyıl becerilerini de kazanabilmektedir. Böylelikle eğitimin temel hedeflerinden biri olan çağın şartlarına uygun vatandaşların yetişmesine katkı sağlanmaktadır. Brown (2018) tarafından ifade edildiği gibi 21. Yüzyıl becerilerinin kazanımını sağlayan okulların PTÖ'ye ağırlık verdiği söylenebilir (akt: Cansoy, 2018). Ancak gerek yurtdışındaki İngilizce araştırmalar arasında gerekse ülkemizde toplu bir değerlendirme ile PTÖ ile kazanılabilen 21. Yüzyıl becerilerinin belirlenmesine yönelik bir araştırmaya rastlanılamamıştır. Bu bağlamda araştırmanın temel amacı, proje tabanlı öğrenme ile kazanılan 21. Yüzyıl becerilerini belirleyebilmektir. Çalışma kapsamında aşağıda belirtilen araştırma sorularına yanıt aranmıştır:

1. Araştırmalarda hangi araştırma modeli kullanılmıştır?

2. Araştırmalar hangi çalışma konularını içermektedir?

3. Araştırmaların hedef kitlesi (çalışma grupları) nedir?

4. Araştırma bulguları dikkate alındığında PTÖ ile hangi 21 Yüzyıl becerileri kazanılabilmektedir?

\section{Araştırmanın Önemi}

Araştırmanın bulgu ve sonuçlarında 21. Yüzyıl becerileri kazanımlarını ifade eden toplam 168 PTÖ araştırmasının toplu olarak incelemesi sonucunda PTÖ ile kazanılabilen 21. Yüzyıl becerilerinin belirlenmesi açısından yerli ve yabancı alanyazında bir ilk olma özelliği taşıdığı düşünülmektedir. Araştırma, PTÖ uygulamalarında farklı 21. Yüzyıl becerilerinin kazandırılmasına yönelik tasarımlar yapılabilmesi adına bir değer taşımakta ve eğitim kurumlarına, uzmanlara, öğretmenlere, öğreticilere bu konuda farklı örnekler ve deneyimler sunmaktadır. Bu bakımdan PTÖ ile 21. Yüzyıl becerileri kazanımlarına yönelik yeni araştırmalara, farklı tasarımlara ilham kaynağ düşünülmektedir.

\section{Araştırmanın Sınırlılığı}

Araştırma belirtilen 4 araştırma sorusu ve ülkemizde 2000-2018 yılları arasında Türkçe ya da İngilizce olarak basılan, bulgu ve sonuçlarında 21. Yüzyıl becerileri kazanımlarını ifade eden 168 PTÖ araştırmasının incelenmesi ile sınırlıdır. Alanyazında 21. Yüzyıl becerilerine yönelik farklı sınıflamalar görülebilmektedir. Bu araştırmada, büyük çoğunluğu Ekici ve arkadaşları (2017) tarafından geliştirilen ve Tablo 5'te görülen 21. Yüzyıl becerileri dikkate alınmıştır.

\section{Yöntem}

\section{Araştırma Modeli}

Temel amacı PTÖ ile kazanılabilen 21. Yüzyıl becerilerinin geliştirilmesine yönelik olan bu araştırma, nitel bir araştırma modeli olarak desenlenmiştir. Nitel araştırma; nitel veri toplama yöntemlerinin kullanıldığı̆, algıların ve olayların doğal ortamda gerçekçi ve bütüncül bir biçimde ortaya konmasına yönelik nitel bir sürecin izlendiği araştırma olarak tanımlanabilir (Yıldırım ve Şimşek, 2003). Nitel araştırmalarda, araştırmacı gözlem, görüşme ve doküman incelemesinden yararlanarak, kavramları, olguları ve ilişkileri açıklamaya çalışır (Merriam, 2013). Bu araştırmada da doküman incelemesinden yararlanılarak PTÖ ile kazanılmış olan 21. Yüzyıl becerileri üzerinde çalışılmıştır. 


\section{Verilerin Toplanması}

Araştırma nitel olarak desenlenmiş bir doküman incelemesidir. Araştırmada, Türkiye'de 20002018 yılları arasında proje tabanlı öğrenmeye yönelik akademik yayınlar YÖK tez merkezi, Tübitak DergiPark, TR DIZIIN, asos index ve Google Scholar aracılığı ile belirlenmiştir. Bu araştırmalar 21. Yüzyıl becerileri bağlamında taranarak bulgularında 21. Yüzyıl becerileri kazanımına yönelik sonuç üretmiş olanlar değerlendirmeye alınmıştır. Doğru ve detaylı bir inceleme yapabilmek için birincil kaynaklar üzerinde çalışılmış, tezden çıkarılan makaleler ve makale olarak basılan konferans bildirileri dikkatli bir şekilde araştırmadan çıkarılmıştır. Araştırmaların tamamı birebir olarak incelenmiş ve araştırmaya yönelik hiçbir ikincil kaynak kullanılmamıştır. Araştırma kapsamında incelenen akademik yayınlar Tablo 1'de verilmiştir.

Tablo 1. Araştırma Kapsamında İncelenen Akademik Yayınlar

\begin{tabular}{lll}
\hline İncelenen Araştırma & $\mathrm{f}$ & $\%$ \\
\hline Yüksek Lisans Tezi & 85 & 50,6 \\
Makale & 54 & 32,1 \\
Doktora Tezi & 26 & 15,5 \\
Bildiri & 3 & 1,8 \\
Toplam & 168 & 100 \\
\hline
\end{tabular}

Tablo 1'de görüldüğü gibi araştırma kapsamında; 26 doktora (Dr) tezi, 85 yüksek lisans (yl) tezi, 54 makale ve 3 bildiri olmak üzerinde toplam 168 akademik yayın üzerinde çalışılmıştır. Bu yayınların tamamı kaynakça bölümünde, kaynak gösteriminin ardından köşeli parantez içinde numaraları ile birlikte verilmiştir. Araştırma, Türkiye'de 2000-2018 yılları arasındaki yayınlara yönelik olduğundan, etik kurul izin belgesi gerekmemektedir.

\section{Verilerin Analizi}

Toplanan 168 akademik yayın, araştırma sorularına yanıt verebilmek için doküman incelemesine tabi tutularak ayrıntılı bir şekilde analiz edilmiştir. Verilerin analiz edilebilmesi için doküman incelemesi ile birlikte nitel betimsel analiz tekniği kullanılmıştır. Betimsel analiz, araştırma konusuna ilişkin alan yazında kavramsal ve kuramsal olarak yeterli açıklamanın olduğu durumlarda kullanılır (Ersoy, 2007, s.102). Alanyazında 21. Yüzyıl becerilerine yönelik yeterli sayıda tema belirleme çalışması yapılmasından dolayı (Ananiadou ve Claro, 2009; Binkley vd., 2012; Ekici vd., 2017; Günüç vd., 2013; P21, 2009) yeniden bir tema belirleme çalışması yapılmasına gerek duyulmamıştır. Araştırmacı, araştırmaların bulguları doğrultusunda nitel betimsel analiz yaparak PTÖ yöntemi ile kazanılan 21. Yüzyıl becerilerini belirlemeye çalışmıştır. Araştırma sorularına yönelik yüzde ve frekans değerleri betimsel istatistik olarak verilmiştir. PTÖ araştırmaları ile kazanılmış 21. Yüzyıl becerilerine yönelik kodlamalar araştırmacı tarafından kodlanmıştır. Bu kodlamalar sonrasında 2 alan uzmanı tarafından incelenmiş, değerlendirilmiş ve kontrol edilmiştir. Yapılan kontrol sonrasında tüm araştırmacılar bir araya gelerek değişiklik önerilerini paylaşmışlar ve fikir alışverişi yaparak görüş birliği içinde kodlamalara son şeklini vermişlerdir.

\section{Bulgular}

\section{Araştırmaların Modeline Yönelik Bulgular}

Proje tabanlı öğrenme ile kazanılmış 21. Yüzyıl becerilerinin belirlenmesine yönelik yürütülen bu araştırma toplam 168 araştırma incelenmiştir. Tablo 2' de görüldüğü gibi bu araştırmaların $64(\% 38,1)$ 
tanesinde deneysel model ve nitel yöntemler birlikte kullanılmış, $60(\% 35,7)$ tanesinde sadece deneysel model kullanılmış, $30(\% 17,8)$ tanesinde sadece nitel yöntem kullanılmış, $7(\% 4,2)$ tanesinde hem nicel hem de nitel yöntem kullanılmış ve $7(\% 4,2)$ tanesinde ise tek başına nicel yöntem kullanılmıştır. Bu sonuçlara göre PTÖ araştırmalarında en çok deneysel modelin $(124-\% 73,8)$ tercih edildiği söylenebilir. Araştırmacılar deneme modeli içinde derinlemesine bilgi toplamak istediklerinde deneysel + nitel yöntemi bir arada kullandıkları görülmektedir. Bu araştırmalar içinde en az tek başına nicel yöntem ile nicel + nitel karma metodunun $(7-\% 4,2)$ tercih edildiği belirtilebilir.

Tablo 2. Araştırmaların Modeline Yönelik Bulgular

\begin{tabular}{lll}
\hline Araştırma Modeli & $\mathrm{f}$ & $\%$ \\
\hline Deneysel+Nitel & 64 & 38,1 \\
Deneysel & 60 & 35,7 \\
Nitel & 30 & 17,8 \\
Nicel+Nitel & 7 & 4,2 \\
Nicel & 7 & 4,2 \\
Toplam & 168 & 100 \\
\hline
\end{tabular}

\section{Araştırmaların Çalışma Konusuna Yönelik Bulgular}

PTÖ araştırmalarında 21. Yüzyıl becerilerinin arandığı 168 araştırma, çalışma konularına göre incelendiğinde 62 frekans ve $(\% 36,9)$ yüzde değeri ile en sık olarak Fen-Teknoloji konusunun çalışıldığ1 görülmektedir. Arkasından çalışma konusu olarak sırasıyla Bilgisayar-Bilgi ve İletişim Teknolojileri (BIT) 23 (\%13,7), Sosyal Bilgiler 21 (\%12,5) Matematik $13(\% 7,7)$ Çevre $10(\% 6)$ ve PTÖ $8(\% 4,7)$ konuları gelmektedir. Araştırmada Fen-Teknoloji başlığı altında Fen Bilgisi, Fen-Teknoloji, Fizik, Kimya, Biyoloji alanlarına yönelik konulara yer verilmiştir. Bilişim-BİT başlığı altında Bilgisayar, Web sayfası, Öğretim Teknolojileri, Materyal Geliştirme konuları bulunmaktadır. Matematik başlığı altında Matematik, Geometri konuları yer almaktadır. Çevre başlığı altına Çevre Bilgisi, Çevre Eğitimi, Geri Dönüşüm konuları dâhil edilmiştir. Araştırmaların çalışma konularına yönelik bulgular Tablo 3'te verilmektedir.

Tablo 3. Araştırmaların Çalışma Konusuna Yönelik Bulgular

\begin{tabular}{lll}
\hline Konu-Alan & $\mathrm{f}$ & $\%$ \\
\hline Fen-Teknoloji & 62 & 36,9 \\
Bilgisayar-Bilgi ve İletişim Teknolojileri & 23 & 13,7 \\
Sosyal Bilgiler & 21 & 12,5 \\
Matematik & 13 & 7,7 \\
Çevre & 10 & 6 \\
PTÖ & 8 & 4,7 \\
Görsel Sanatlar & 7 & 4,1 \\
İngilizce & 6 & 3,6 \\
Türkçe & 6 & 3,6 \\
Din Kültürü & 2 & 1,2 \\
Vatandaşlık Bilinci & 1 & 0,6 \\
Bütünleşik (Fen Türkçe Sosyal) & 1 & 0,6 \\
STEM & 1 & 0,6 \\
Sağlık & 1 & 0,6 \\
Tarih & 1 & 0,6 \\
Hayat Bilgisi & 1 & 0,6 \\
Takı Tasarımı & 1 & 0,6 \\
Farklı Kültürler & 1 & 0,6 \\
\hline
\end{tabular}




\begin{tabular}{lll}
\hline Topluma Hizmet & 1 & 0,6 \\
Planlama Değerlendirme & 1 & 0,6 \\
Toplam & 168 & $\% 100$ \\
\hline
\end{tabular}

Araştırma kapsamı içinde iki araştırma (\%1,2) ile Din Kültürü ve birer araştırma $(\% 0,6)$ ile üzerinde en az çalışılan konuların; Vatandaşlık Bilinci, Fen Türkçe ve Sosyal Bilgilerden oluşan Bütünleşik Konular, STEM, Sağlık, Tarih, Hayat Bilgisi, Takı Tasarımı, Farklı Kültürler, Topluma Hizmet ve Planlama Değerlendirme olduğu anlaşılmaktadır. Belirtilen konular toplum, sağllk, tarih, kültür vb. olarak oldukça önemli olmakla birlikte, bu konularda zaman içinde daha fazla araştırma yapılabilir. P21 (2009) tarafından 21. Yüzyıl temaları; dil edinimi, sanat, matematik, fen/bilim, coğrafya, tarih, devlet ve vatandaşlık olarak 21 Yüzyıl disiplinlerarası temaları ise sağlık okuryazarlığı ve çevre okuryazarlığı vb. konular olarak bildirilmektedir. Bu bağlamda 21. Yüzyıl becerileri de dikkate alınarak (bilgisayar okuryazarlığı, kültürel farkındalık, proje yönetebilme vb.) çalışma konularının neredeyse tamamının 21. Yüzyıl Beceri Konuları ile bağlantılı olması oldukça değerlidir.

\section{Araştırmaların Hedef Kitlesine Yönelik Bulgular}

PTÖ araştırmalarında 21. Yüzyıl becerilerinin arandığı bu yayınlarda hedef kitle olarak en sık 68 frekans ve $(\% 40,4)$ yüzde değeri ile ortaokul ve 48 frekans ve $(\% 28,6)$ yüzde değeri ile lisans düzeyi olduğu söylenebilir. Arkasından ilkokul 20-(\%11,9) ve lise düzeyinde 19-(\%11,3) PTÖ araştırmaları yapıldığı belirtilebilir. Okulöncesine yönelik PTÖ araştırmalarının az sıklıkta 5-(\%3) gerçekleştiği ifade edilebilir. PTÖ'nün tutum değiştirebilme etkisi dikkate alınıp, okulöncesi ve ilkokulda daha fazla PTÖ uygulaması yapılarak 21.Yüzyıl becerileri daha erken yaşlarda öğrencilere kazandırılabilir. Belki araştırmaya getirebileceği iş yükünden ötürü, 4-(\%2,4) frekans ve yüzde değeri ile karma çalışma gruplarına da çok rastlanılmamıştır. Yetişkinler için 21 Yüzyıl beceri kazanımlarına yönelik PTÖ araştırmaları da 2-(\%1,2) frekans ve yüzde değeri ile oldukça sınırlı sayıda kalmıştır. Bunlara ek olarak en az rastlanan hedef kitle; 1-(\%0,6) frekans ve yüzde değeri ile lisansüstü ve önlisans düzeyleri olarak karşımıza çıkmaktadır. Tablo 4'te araştırmaların hedef kitlesine yönelik bulgular yer almaktadır.

Tablo 4. Araştırmaların hedef kitlesine yönelik bulgular

\begin{tabular}{lll}
\hline Hedef Kitle & $\mathrm{f}$ & $\%$ \\
\hline Ortaokul & 68 & 40,4 \\
Lisans & 48 & 28,6 \\
İlkokul & 20 & 11,9 \\
Lise & 19 & 11,3 \\
Okulöncesi & 5 & 3 \\
Karma & 4 & 2,4 \\
Yetişkin & 2 & 1,2 \\
Lisansüstü & 1 & 0,6 \\
Önlisans & 1 & 0,6 \\
Toplam & 168 & 100 \\
\hline
\end{tabular}

\section{Araştırmalarda PTÖ ile Kazanılmış 21. Yüzyıl Becerilerine Yönelik Bulgular}

Araştırma kapsamında PTÖ ile kazanılan 21. Yüzyıl becerilerini belirleyebilmek için Ekici ve arkadaşları (2017, s.130) tarafından 19 farklı kaynaktan içerik analiz sonucunda elde edilen temalar dikkate alınmıştır. Araştırmada ortaya çıkan bulgular göz önünde bulundurularak ilgili 21. Yüzyıl becerileri form üzerine kayıt edilmiştir. Tablo 5'te PTÖ ile kazanılan 21. Yüzyıl becerilerine yönelik bulgular görülmektedir. 
Tablo 5. PTÖ ile Kazanılan 21. Yüzyıl Becerilerine Yönelik Bulgular

\begin{tabular}{|c|c|c|}
\hline PTÖ Araştırmalarında 21.Yüzyıl Becerileri & $\mathbf{f}$ & $\%$ \\
\hline İletişim & 103 & 61,3 \\
\hline İşbirliği & 102 & 60,7 \\
\hline Araştırma & 98 & 58,3 \\
\hline Bilgi Okuryazarlığı & 92 & 54,8 \\
\hline Akademik Başarı & 92 & 54,8 \\
\hline Üretkenlik-Verimlilik & 86 & 51,2 \\
\hline Motivasyon & 80 & 47,6 \\
\hline Yenilik-Yaratıcılık & 79 & 47 \\
\hline Düşünme Becerileri & 70 & 41,7 \\
\hline Sorumluluk & 65 & 38,7 \\
\hline Problem Çözme & 57 & 33,9 \\
\hline Tutum Geliştirme & 53 & 31,5 \\
\hline Kalıcı Öğrenme & 44 & 26,2 \\
\hline Özgüven & 37 & 22 \\
\hline Karar Verme, Aktif Katılım & 35 & 20,8 \\
\hline Zaman Yönetimi & 34 & 20,2 \\
\hline BİT Okuryazarlığı, Planlı Çalışma & 33 & 19,6 \\
\hline Öğrenmeyi Öğrenme & 19 & 11,3 \\
\hline Öz Yönetim & 18 & 10,7 \\
\hline Medya Okuryazarlığı & 17 & 10,1 \\
\hline Çevre Okuryazarlığı & 16 & 9,5 \\
\hline Sosyal Kültürel Beceriler & 15 & 8,9 \\
\hline Merak & 14 & 8,3 \\
\hline Esneklik ve Uyum & 13 & 7,7 \\
\hline Bağımsız Çalışma, Farklılıklara Değer Verme & 12 & 7,1 \\
\hline Çözümleme-Analiz, Yaşam Boyu Öğrenme, Liderlik & 9 & 5,4 \\
\hline Girişimcilik, Kariyer, Proje Yönetme, Topluma Hizmet & 8 & 4,8 \\
\hline Bilginin Farklı Alanlara Aktarılması, Kendini Tanıma, Öz Yeterlik & 7 & 4,2 \\
\hline Görsel Okuryazarlık, Sorgulama, Uzlaşma-Çatışma Çözme & 6 & 3,6 \\
\hline Etik & 5 & 3,0 \\
\hline Yabancı Dil Becerisi, Empati, Risk Alma, Sabır & 4 & 2,4 \\
\hline Kültürel Farkındalık & 3 & 1,8 \\
\hline Ekonomi Okuryazarlığı & 2 & 1,2 \\
\hline Azim, Sağlık, Hesap Verebilirlik, Karakter Eğitimi, Öz Değerlendirme & 1 & 0,6 \\
\hline Küresel-Yerel Vatandaşlık, Önyargıların Üstesinden Gelme & 1 & 0,6 \\
\hline
\end{tabular}

Tablo 5 incelendiğinde PTÖ ile en sık kazanıldığı belirtilen 21. Yüzyıl becerilerinin sırasıyla 103$(\% 61,3)$ frekans ve yüzde değerleri ile iletişim, 102-(\%60,7) değerleri ile işbirliği, 98-(\%58,3) değerleri ile araştırma, 92-(\%54,8) değerleri ile bilgi okuryazarlığ geldiği görülmektedir. Arkasından 86-(\%51,2) frekans ve yüzde değerleri ile üretkenlik-verimlilik, 80-(\%47,6) değerleri ile motivasyon, 79-(\%47) değerleri ile yenilik-yaratıcılık, 70-(\%41,7) değerleri ile düşünme becerileri, 65-(\%38,7) değerleri ile sorumluluk ve 57-(\%33,9) değerleri ile problem çözme olduğu söylenebilir. Belirtilen becerilerin araştırmalarda yüksek oranda görülmesi, çalışma konularından bağımsız olarak PTÖ'nün iki temel unsuru olan proje ve öğrenme konularının problem, çözüm, iletişim, özgünlük, üretim, bilgi vb. temel dinamiklerinden kaynaklandığı ifade edilebilir. Tutum geliştirme de $53-(\% 31,5)$ frekans ve yüzde değeri 
ile PTÖ sayesinde kazanılabilen önemli bir özellik olarak vurgulanabilir. Araştırma bulgularına göre PTÖ'nün 92-(\%54,8) frekans ve yüzde değeri ile akademik başarıyı olumlu etkilediği söylenebilir.

Araştırma kapsamında PTÖ ile en az kazanıldığı belirtilen 21. Yüzyıl becerilerinin 3-(\%1,8) frekans ve yüzde değeri ile kültürel farkındalık, 2-(\%1,2) değerleri ile ekonomi okuryazarlığı ve 1-(\%0,6) değerleri ile azim, sağlık, hesap verebilirlik, karakter eğitimi, küresel-yerel vatandaşlık, önyargıların üstesinden gelme ve öz değerlendirme olduğu ifade edilebilir.

21. Yüzyıl becerileri arasında gösterilmesine rağmen PTÖ ile kazanıldığına dair bir bulguya rastlanamayan bazı beceriler olduğu ifade edilebilir. İncelenen yayınlar içinde kaynakların etkili kullanımı, estetik ve kültürel takdir ve dijital vatandaşlık konularında bir beceri kazanımına rastlanılamadığı söylenebilir. Ekici ve arkadaşları (2017) tarafından 21. Yüzyıl becerilerine yönelik 19 farklı çalışma içerik analizine tabi tutularak 21. Yüzyıl becerilerinin tekrarlanma sıklıkları belirlenmiştir. Buna göre kaynakların etkili kullanımı 1-(\%5,3) ve estetik ve kültürel takdir 2-(\%10,5) en düşük tekrarlanma sıklığı olan 21. Yüzyıl becerileri arasında gösterilmiştir. Bu sonuç araştırmayı destekler niteliktedir. Bir projenin varlığına dayalı olan PTÖ'de kaynakların etkili kullanımı aslında karşılaşılabilecek bir özellikken, alanyazında PTÖ araştırmalarında çok fazla üzerinde durulan bir beceri olmadığı gözlenmiştir. Yine estetik ve kültürel takdir becerisi de çalışma konusu olarak daha çok mimari projelerde, 3 boyutlu tasarımlarda tercih edilebildiğinden incelenen PTÖ araştırmalarında karşılaşılmadığı düşünülmektedir. Estetik ve kültürel takdir becerisine çalışma konusu takı tasarımı olan bir araştırmada (Kalaycı, 2008, s.98) proje gruplarının kendi grup üyelerini değerlendirme ölçütleri arasında "Tasarımlar Güzel ve Uygulanabilir" ifadesi ile çok yaklaşıldığı görülmüştür.

Küresel-yerel vatandaşlık, kültürel farkındalık, sağlık, yabancı dil, dijital vatandaşlık, estetik ve kültürel takdir gibi 21. Yüzyıl becerilerinin PTÖ'nün iç dinamikleri ile çok gelişemediği ancak uygun çalışma konuları ile PTÖ gerçekleştirildiğinde bu becerilerin kazanılabildiği anlaşılmıştır. Bu belirtilen becerilerin kazanımına bir engel olarak görülmemelidir. Çünkü PTÖ, planlama ve tasarıma bağlı olarak her zaman istenilen bir çalışma konusu ile birlikte gerçekleştirilebilmektedir.

Fadel ve arkadaşları $(2015$, s.85) tarafından karakter eğitiminin öğeleri düşünceli olma, cesaret, esneklik, merak, etik ve liderlik olarak tanımlanmıştır. Araştırmada PTÖ ile üst başlık bağlamında karakter eğitimi $(1-\% 0,6)$ ve karakter eğitiminin alt başlıkları olan esneklik $(13-\% 7,7)$, merak $(14-\% 8,3)$, etik (5-\%3) ve liderlik $(9-\% 5,4)$ becerileri kazanılabildiği gözlenmiştir. Bu tür doküman analizi ve içerik analizi araştırmalarında yapılan sınıflamalara bağlı olarak frekans ve yüzde bilgilerinin değişebileceği dikkate alınmalıdır. Araştırmalarda alt başlıkların önem taşıdığı durumlarda bu tarz sınıflamalar yapılabilmektedir. Benzer bir örnek proje yönetebilme $(8-\% 4,8)$ becerisi ve bu başlığın alt başlıkları olan zaman yönetimi $(34-\% 20,2)$, planlı çalışma $(33-\% 19,6)$ ve çözümleme $(9-\% 5,4)$ becerilerinde de görülebilmektedir. Araştırmalarda alt başlıklar, üst başlı̆̆1 yeterince kapsayamadığı ve üst başlığın alt başlık ile bağlantısının verilmediği durumlarda da bu tür sonuçlar görülebilmektedir.

Yapılan araştırmada incelenen yayınlarda çok sınırlı sayıda araştırmada $(2-\% 1,2)$ hedef kitleye bir bütçeye dayalı olarak PTÖ uygulaması yaptırılmıştır. Bu yüzden ekonomi okuryazarlığı becerisine yönelik kazanım da çok az sayıda gerçekleştiği söylenebilir. Ayrıca, topluma hizmet ve planlama konuları sadece birer araştırmada doğrudan çalışılmasına rağmen araştırma sonuçları bir 21. Yüzyıl becerisi olarak gösterilen toplum hizmet becerisinin $(8-\% 4,8)$ ve planlama becerisinin $(33-\% 19,6)$ frekans ve yüzde değeri olan kazanımlar olduğuna işaret etmiştir. Bu sonuç doğrultusunda, proje çıtı ve ürünleri sayesinde PTÖ'nün topluma hizmet noktasında bağımsız bir araç, bir yöntem olarak kullanılabileceğini söylenebilir. Benzer şekilde planlama becerisinin de çalışma konusundan bağımsız olarak PTÖ ile kazanılabilen bir 21. Yüzyıl becerisi olduğu ifade edilebilir. 


\section{Sonuç Tartışma ve Öneriler}

PTÖ; problem tabanlı öğrenme, aktif öğrenme, sosyal öğrenme, takım halinde öğrenme ve buluş yoluyla öğrenme gibi etkili öğrenme yöntemlerini birleştirerek daha sinerjik bir öğrenme yöntemi haline dönüşebilmektedir. Bu yönüyle PTÖ farklı öğrenme yöntemlerindeki kazanımlara da sahip olarak, öğrenenler için bilgi beceri ve tutum açısından daha anlamlı bir öğrenme ortamına fırsat verebilmektedir. Bu yüzden günümüzde okulların da proje tabanlı okullara dönüşmesi yerinde bir uygulama olarak düşünülebilir. Fatmawati $(2018$, s.45) ve Gültekin $(2005$, s.553) tarafından belirtildiği gibi PTÖ yöntemi ile bu kapsamlı öğrenme çıktılarından etkili bir şekilde yararlanabilmek için PTÖ yönteminin temel öğelerini ve uygulama aşamalarını dikkate alarak bir öğrenme-öğretim tasarımı yapmak gerekmektedir.

PTÖ ile kazanılan 21. Yüzyıl becerilerinin belirlenmesine yönelik bu araştırmada toplam 168 akademik yayın incelenmiştir. İnceleme sonuçlarına göre 21. Yüzyıl becerileri kazanımına yönelik PTÖ araştırmalarında en çok deneysel modelin $(124-\% 73,8)$ tercih edildiği görülmüştür. İncelenen araştırmalar bir yöntemin etkililiğini belirlemeye çalıştığından deneysel modellerin kullanılması araştırma yöntemleri açısından beklenen bir sonuç olarak değerlendirilebilir. Araştırmalara yönelik daha derin bilgi toplanabilmesi için deneysel modeller nitel araştırma yöntemleri ile desteklendiği belirlenmiştir. Çelik ve arkadaşları (2016) tarafından yapılan araştırmada da benzer şekilde en çok deneysel araştırmalara yer verildiği ve deneysel modellerin ardından en fazla karma modelin kullanıldığı ifade edilmiştir. İncelenen araştırmalarda en az nicel model ile karma modelin kullanıldığı belirlenmiştir.

Araştırmalar çalışma konularına göre incelendiğinde Demiray (2013) ve Kaşarcı (2013) ile benzer şekilde en sık Fen-Teknoloji konusunun çalışıldığı görülmüştür. Ayaz (2014) ve Balemen (2016) tarafından yapılan meta analiz araştırması da fen derslerine yönelik olarak gerçekleştirilmiştir. Bunun en önemli nedeni olarak bu alanda yapılan araştırma sayısının yeterli çoğunlukta olması gösterilebilir. Çalışma konusu olarak sonrasında sırasıyla Bilgisayar-BİT, Sosyal Bilgiler, Matematik, Çevre ve PTÖ konularının geldiği görülmüştür. Araştırma kapsamı içinde iki araştırma ile Din Kültürü ve birer araştırma ile üzerinde en az çalışılan konuların; Vatandaşlık Bilinci, Fen Türkçe ve Sosyal Bilgilerden oluşan Bütünleşik Konular, STEM, Sağlık, Tarih, Hayat Bilgisi, Takı Tasarımı, Farklı Kültürler, Topluma Hizmet ve Planlama Değerlendirme olduğu anlaşılmaktadır. Demiray (2013) ve Kaşarcı (2013) da PTÖ yöntemi ile araştırma bulgularında yer alan İngilizce, sosyal bilgiler ve matematik, güzel sanatlar, çevre eğitiminin çalışılan konular arasında olduğunu ve din kültürünün PTÖ ile az çalışılan bir konu olduğunu bildirmektedir. Guo ve Yang (2012) araştırmalarında sırasıyla en çok Fen-Matematik, Yaşam Becerileri, Coğrafya ve Çevre, Tarih ve Kültür, Sağlık, Bilim ve Teknoloji, Meteroloji ve Astronomi ve Hukuk ve Güvenlik konularında çalışıldığını belirtmiştir. İncelenen 168 araştırmadan neredeyse tamamının çalışma konuları bağlamında 21. Yüzyıl temaları ile uyumlu olduğu görülmüştür.

PTÖ araștırmalarında 21. Yüzyıl becerilerinin arandığı araştırmalarda hedef kitle olarak en sık ortaokul ve lisans düzeyi olduğu söylenebilir. Arkasından ilkokul ve lise düzeyinde PTÖ araştırmaları yapıldığı belirtilebilir. Okul öncesine yönelik PTÖ araştırmalarının daha az sıklıkta gerçekleştiği ifade edilebilir. Yetişkinlere, lisansüstü ve önlisansa yönelik PTÖ araştırmalarının ise son derece sınırlı olduğu ortaya çıkmıştır. Balemen (2016) ve Çelik ve arkadaşları (2016) tarafından yapılan araştırmada sırasıyla en çok ortaokul+ilkokul, üniversite ve lise düzeyleri ile çalışmalar yapılması araştırmaların hedef kitle açısından benzer bir sıralama içinde olduğunu göstermektedir. Ayaz (2014) tarafından yapılan araştırmada okul öncesi kapsam dışı kalmakla birlikte hedef kitle düzeyine yönelik aynı sıralama elde edilmiştir. Demiray (2013) ve Kaşarcı (2013) da ilkokul, ortaokul, lise ve üniversitelere yönelik yaptıkları araştırmalarda, araştırmaya benzer şekilde en çok ortaokul düzeyinde, en az da lise düzeyinde çalışmaya ulaştıklarını belirtmişlerdir. 
PTÖ ile en sık kazanılan 21. Yüzyıl becerilerinin sırasıyla iletişim, işbirliğiı, araştırma ve bilgi okuryazarlığı olduğu görülmektedir. Arkasından üretkenlik-verimlilik, motivasyon, yenilik-yaratıcılık, düşünme becerileri, sorumluluk, problem çözme ve kalıcı öğrenmenin olduğu ifade edilebilir. Talat ve Chaudhry (2014) tarafından yapılan araştırmada PTÖ ile 21. Yüzyıl becerileri arasında pozitif bir ilişki bulunmuştur. Bu araştırmaya katılan özel okulların \%80'den fazlası PTÖ ile yenilik-yaratıcılık, eleştirel düşünme, problem çözme, iletişim, işbirliği, bilgi okuryazarlığı, araştırma ve sorgulama, medya okuryazarlığı, BiंT okuryazarlığı, esneklik ve uyum, girişimcilik ve özdenetim, üretkenlik, liderlik ve sorumluluk becerileri kazandırmayı kurumsal politikalarının bir parçası olduğunu bildirmişlerdir. Özel okullar içinde Dijital vatandaşlığın \%40 ile en az desteklenen beceri olduğu anlaşılmıştır. Wurdinger ve Rudolph (2009) tarafından yapılan araştırmada, PTÖ uygulamaları yapan katılımcılar PTÖ sayesinde \%94 oranında yenilik-yaratıcılık, \%89 oranında problem çözme, \%84 oranında karar verme, \%77 oranında zaman yönetimi, \%92 oranında araştırma, \%89 oranında bilgi okuryazarlığı becerilerine güzel ve mükemmel düzeyde sahip olduklarını dile getirmişlerdir.

Çelik ve arkadaşları (2016) da PTÖ araştırmalarında daha çok akademik başarı, tutum ve kalıcılığa yönelik çalışıldığını ifade etmektedir. Araştırma sonucuna benzer bir şekilde Musa ve arkadaşları (2012) tarafından yapılan araştırmada katılımcılar \%79,3 oranında işbirliği, \%75,1 oranında iletişim, \%68,9 oranında problem çözme ve \%67,3 oranında proje yönetimi becerilerinin PTÖ ile kazanılabildiğini belirtmişlerdir. Lin ve arkadaşları da (2015) yaptıkları araştırmada frekans ve yüzde bilgisi vermeden PTÖ ile iletişim, işbirliği, yenilik-yaratıcılık, problem çözme, düşünme becerileri, aktif katılım, BiंT okuryazarlığı, sorumluluk, zaman yönetimi becerilerinin kazanılmasının yanında bu becerilerin geliştirilip güçlendirilebildiğini ifade etmiştir. Hasni ve arkadaşları (2016) inceledikleri 48 makale kapsamında PTÖ ile kazanılabilen 21. Yüzyıl becerilerini; problem çözme, üretkenlik, aktif katılım, iletişim, işbirliği, BİT okuryazarlığı, motivasyon ve tutum geliştirme, araştırma, sorgulama, bilgi okuryazarlığı, yenilik-yaratıcılık, düşünme becerileri, sorumluluk, özdenetim, merak, proje yönetebilme olarak dile getirmişlerdir.

Meyer ve Wurdinger (2016) ile Wurdinger ve Qureshi (2015) de araştırma sonuçlarını destekleyerek iletişim, işbirliği, problem çözme, sorumluluk, zaman yönetimi, yenilik-yaratıcllık, özdenetim ve etik becerileri kazanımını pozitif etkilediğini bildirmişlerdir. Ravitz ve arkadaşları (2012) tarafından yapılan araştırmada, eleştirel düşünme, işbirliği, iletişim, yenilik-yaratıcılık, özdenetim ve teknoloji kullanımı olarak belirtilen 21. Yüzyıl becerilerinin PTÖ ile öğretiminde anlamlı bir fark olduğu bulunmuştur.

Gou ve Yang (2012) tarafından gerçekleştirilen araştırmada katılımcı öğrenciler tarafından PTÖ’nün \%84 oranı ile özgüven, \%83,8 oranı ile motivasyon, $\% 77,3$ oranı ile araştırma, $\% 76,2$ oranı ile işbirliği, \%74,1 oranı ile BİT okuryazarlığı, \%73,9 oranı ile iletişim, \%72,3 oranı ile bilgi okuryazarlık, $\% 70,8$ oranı ile tutum, $\% 53,3$ oranı ile problem çözme, $\% 51,4$ oranı ile düşünme becerilerini geliştirdiği belirtilmiştir. Bu araştırmada duyuşsal alana yönelik olan özgüven, motivasyon ve tutumun yapılan araştırma sonuçlarına göre yüksek çıkması araştırmanın doğu kültürüne sahip Çin'de yapılmış olması ve duyuşsal özelliklerin ön planda tutulduğu kültürel değerlerden kaynaklandığı düşünülmektedir.

Tutum geliştirme de $(53-\% 31,5)$ PTÖ ile kazanılabilen önemli bir özellik olarak vurgulanabilir. Gerek konulara gerek etkinliklere yönelik olumlu tutum sahibi olmayan öğrenciler, öğrenenler için bu bulgu eğitim ve öğrenme açısından oldukça önemli bir sonuç olarak değerlendirilebilir. Özellikle bilgiyi işleme kuramında öğrenmenin duyusal kayıt ile başladığı ve bunu başlatanın motivasyon, öğrenme isteği ve olumlu tutum olduğu düşünülürse bu bağlamda bu sonucun öğrenme adına çok değerli bir kazanım olduğu söylenebilir. Kaldı ki PTÖ, motivasyon için de $(80-\% 47,6)$ değeri ile ciddi bir kaynak olarak görülmektedir. Ayaz (2014) ile Guo ve Yang (2012), Hasni ve arkadaşları (2016) ve Kaşarcı (2013) tarafından yapılan araştırmalar da tutum geliştirmeye yönelik bu olumlu sonucu desteklemektedir. 
Akademik başarı, doğrudan bir 21. Yüzyıl beceri olarak gösterilmese de öğrenme kazanımlarını temsil ettiğinden eğitim ve öğrenme açısından yıllardır ciddi bir değer taşımaktadır. Bu bağlamda 21. Yüzyıl becerilerinin arandığı PTÖ araştırmalarında 92-(\%54,8) frekans ve yüzde değeri ile akademik başarı noktasında olumlu etki ortaya çıkması kayda değer olarak gösterilebilir. Alanyazında bu sonucu destekleyen araştırmalar da yer almaktadır (Ayaz, 2014; Demiray, 2013; Guo ve Yang, 2012; Gültekin, 2005; Hasni vd., 2016; Thomas, 2000). Balamen (2016) akademik başarıya yönelik olan sonucu destekler nitelikte fen eğitiminde PTÖ yönteminin geleneksel öğrenme yaklaşımlarına göre \%86 daha etkili olduğunu belirtmiştir.

Araştırma kapsamında PTÖ ile en az kazanıldığı belirtilen 21. Yüzyıl becerilerinin; kültürel farkındalık, ekonomi okuryazarlığı ve azim, sağlık, hesap verebilirlik, karakter eğitimi, vatandaşlık, önyargıların üstesinden gelme ve öz değerlendirme olduğu ifade edilebilir. Tüm 21. Yüzyıl becerilerinin önemli olduğu düşünülerek yakın zaman içinde PTÖ ile az kazanıldığı belirlenen becerilere yönelik yeni araştırmaların yapılmasının yerinde ve anlamlı olacağı belirtilebilir.

Son olarak araştırmaya yönelik şu öneriler yapılmaktadır:

- Engelliler için de uygun olduğu bildirilen PTÖ kullanılarak hedef kitle için yeni uygulamalara yer verilebilir.

- Yabancı dil öğreniminde başarıyı artırdığı görülen PTÖ ile konuya yönelik yeni projeler geliştirilebilir.

- Çalışılan konuların da kazanılan becerileri etkilediği gerçeği dikkate alınarak, ihtiyaçlara yönelik konularda PTÖ uygulamaları tasarımlanabilir.

- Öğretmenlere ve öğreticilere mesleki gelişim bağlamında PTÖ ile 21. Yüzyıl becerileri kazanımı yönelik seminerler verilebilir.

- PTÖ araştırmalarında çok ciddi bütçeler ayırmadan öğrenenlerin aileleri desteği ile ekonomi okuryazarlı̆̆ konusunda kendilerini geliştirebilecekleri PTÖ uygulamalarının yerinde olabileceği değerlendirilmektedir.

- Araştırma bulguları doğrultusunda PTÖ'nün araştırma, akademik başarı, düşünme becerileri, yenilik, üretim, sorumluluk ve motivasyon becerilerine katkısı dikkate alınarak, PTÖ ile ekonomik kalkınmanın anahtarı olan Ar\&Ge'ci bireyler yetiştirilmesine katkı sağlanabilir.

- Araştırma bulguları ışı̆̆ında yetişkin, önlisans vb. PTÖ uygulamaları ile 21. Yüzyıl becerileri kazanımlarında zayıf kalan hedef kitlelere yönelik farklı PTÖ uygulamaları ile 21. Yüzyıl becerileri kazanımlarına yönelik yeni fırsatlar sunulabilir. Araştırma kapsamında görece zayıf bir hedef kitle olan İlkokullara yönelik 21. Yüzyıl becerileri açısından zenginleştirilmiş yeni PTÖ uygulamaları tasarımlanabilir ve eğitim kurumlarında uygulamaya geçilebilir.

- Araştırma sonuçlarına göre PTÖ ile güçlü bir şekilde kazanılabilen 21. Yüzyıl becerilerinden biri de tutumdur. Farklı araştırmaların da bu bulguyu desteklediği görülmektedir (Ayaz, 2014; Guo ve Yang, 2012; Hasni vd., 2016; Kaşarc1, 2013). Bu bağlamda hedef kitlenin olumsuz tutumlara sahip olduğu konularda, motivasyon artırıcı özelliği de olan PTÖ uygulamaları ile tutumlar daha da olumlu hale getirilerek daha yüksek bir akademik başarı elde edilebileceği düşünülmektedir.

\section{Araştırma ve Yayın Etiği Beyanı}

Araştırma, Türkiye' de 2000-2018 yılları arasındaki yayınlara yönelik olduğundan, etik kurul izin belgesi gerekmemektedir.

\section{Kaynakça}


Acar, E. N. (2011). Proje tabanlı öğrenmenin fen bilgisi öğretmen adaylarının bilimsel süreç becerilerine ve biyolojiye yönelik tutumlarına etkisi (Basılmamış yüksek lisans tezi). Çanakkale 18 Mart Üniversitesi, Çanakkale. [1]

Acaray, C. (2014). Fen ve teknoloji öğretiminde proje tabanl öğrenme yönteminin çevre bilgisine ve enerji farkındalığına etkisi (Basılmamış yüksek lisans tezi). Gaziosmanpaşa Üniversitesi, Tokat. [2]

Ada, S., Baysal, Z. N. ve Kadığlu, H. (2009). Projeye dayalı öğrenme yaklaşımı'nın öğrencilerin sosyal bilgiler dersine ilişkin tutumlarına ve görsel sunu uygulamalarına etkisi. Ahi Evran Üniversitesi Eğitim Fakültesi Dergisi, 10(3), 89-96. [3]

Aldemir, S. B. (2013). Proje tabanlı öğrenme yönteminin biyoloji öğretmen adaylarmın akademik başarısı ve eleştirel düşünme becerisi üzerine etkisi (Basılmamış yüksek lisans tezi). Gazi Üniversitesi, Ankara. [4]

Alioğlu, E. (2014). Proje tabanlı öğrenme yaklaşımının ortaokul 6.sınıf görsel sanatlar dersi ebru ünitesinin öğrenci başarısına, tutumuna ve kalıcılı̆̆a etkisi (Basılmamış yüksek lisans tezi). Dicle Üniversitesi, Diyarbakır. [5]

Altınpulluk, H. ve Yıldırım, Y. (2021). 2010-2019 yılları arasında yayınlanan 21. yüzyıl becerileri araştırmalarının incelenmesi. Anadolu Journal of Educational Sciences International, 11(1), 438-461.

Anagün, Ş. S., Atalay, N., Kılıç, Z. ve Yaşar, S. (2016). Öğretmen adaylarına yönelik 21. Yüzyıl becerileri yeterlilik algıları ölçeğinin geliştirilmesi: Geçerlik ve güvenirlik çalışması*. Pamukkale University Journal of Education, (40), 160-175.

Ananiadou, K. \& Claro, M. (2009). 21st century skills and competences for new millennium learners in OECD countries. OECD education working papers, No. 41, OECD Publishing.

Arıbaş, S. ve Fırat, Ş. (2010). İlköğretim 4. sınıf öğrencilerinin sosyal bilgiler dersine yönelik akademik başarıları üzerinde proje tabanlı öğrenme yaklaşımının etkisi. Milli Ĕ̆gitim Dergisi, 186, 310-319. [6]

Asan, A. \& Haliloğlu, Z. (2005). Implementing project based learning in computer classroom. The Turkish Online Journal of Educational Technology-TOJET, 4(3). [7]

Asilsoy, Ö. (2007). Ortaöğretim fen ve matematik alanları eğitimi anabilim dalı biyoloji öğretmenleri için ptö yaklaşımı konulu bir hizmetiçi eğitim kurs programı geliştirilmesi ve etkililiğinin araştırılması (Basılmamış yüksek lisans tezi). Karadeniz Teknik Üniversitesi, Trabzon. [8]

Aslan, Ö. (2009). Proje tabanl öğrenme yaklaşımının ilköğretim öğrencilerinin fen ve teknoloji dersine yönelik motivasyonlarına ve bilimin doğasını anlama düzeylerine etkisi (Basılmamış yüksek lisans tezi). Hacettepe Üniversitesi, Ankara. [9]

Aslantaş, S. (2008). İlköğretim II. kademe proje tabanlı öğrenme yönteminin görsel sanatlar dersine katkısı (Basılmamış yüksek lisans tezi). Gazi Üniversitesi, Ankara. [10]

Atar, İ. G. (2009). Meslek lisesinde proje tabanl öğrenme (Salihli imkb anadolu teknik lise, teknik lise ve endüstri meslek lisesi örneği) (Basılmamış yüksek lisans tezi). Balıkesir Üniversitesi, Balıkesir. [11]

Atıcı, B. ve Polat, H. (2010). Web tasarımı öğretiminde proje tabanlı öğrenme yaklaşımının öğrencilerin akademik başarısı ve görüşlerine etkisi. Türk Bilgisayar ve Matematik Eğitimi Dergisi, 1(2), 122-132. [12]

Atik, C. (2009). İlköğretim fen ve teknoloji öğretiminde proje tabanlı öğrenme yaklaşımının öğrencilerin akademik başarıları üzerine etkisi ) (Basılmamış yüksek lisans tezi). Süleyman Demirel Üniversitesi, Isparta. [13] 
Avc1, A. (2006). Bilgisayar ve öğretim teknolojileri eğitimi anabilim dalı elektronik eğitim seti tasarımında entegre programlama yazılımı ile desteklenen proje tabanlı öğrenmenin öğrencilerin elektronik devre tasarımı yapma ve geliştirme performanslarına ve kalıcılı̆̆a etkisi (Basılmamış yüksek lisans tezi). Çukurova Üniversitesi, Adana. [14]

Avcı, E., Su Özenir, Ö. ve Yücel, E. (2016). Students' experiences during Tübitak secondary education students' research projects competition and its contribution to their university life*. Uşak Üniversitesi Sosyal Bilimler Dergisi, 9(3), 1-21. [15]

Avşar, Ö. (2017). İngiliz dili eğitiminde proje tabanlı öğrenmenin uygulanması üzerine bir araştırma (Basılmamış yüksek lisans tezi). Çağ Üniversitesi, Mersin. [16]

Ay, Ş. (2013). Öğretmen adaylarının proje tabanlı öğrenme ve geleneksel öğretime ilişkin görüşleri. Hacettepe Üniversitesi Ĕ̆itim Fakültesi Dergisi, 28(1), 53-67. [17]

Ayan, M. (2012). Proje tabanlı öğrenme yaklaşımının ilköğretim öğrencilerinin fen bilgisi dersi akademik başarı düzeyine etkisi. Türk Eğitim Bilimleri Dergisi, 10(1), 167-183. [18]

Ayas, C., Çeken, R., Eş, H. ve Taştan, B. (2013). “Bu benim eserim” fen bilimleri projelerinde vatandaşlık eğimi açısından sosyal sorumluluk ve vatandaşlık bilinci. Adıyaman Üniversitesi Sosyal Bilimler Enstitüsü Dergisi, (14), 1-19. [19]

Ayaz, M. F. (2014). Proje tabanlı öğrenme yaklaşımının öğrencilerin fen derslerindeki akademik başarılarına ve fen derslerine yönelik tutumlarına etkisi: Bir meta-analiz çalışması (Basılmamış doktora tezi). Dicle Üniversitesi, Diyarbakır.

Aydın, S. (2012). Proje tabanlı öğrenme ortamlarının biyoloji öğretmen adaylarının öz-düzenleme seviyeleri ve öz-yeterlik inançları üzerine etkisi (Basılmamış doktora tezi). Gazi Üniversitesi, Ankara. [20]

Aydın, S., Demir Atalay, T. Ve Göksu, V. (2018). Project-based learning practices with secondary school students. International Online Journal of Educational Sciences, 10(3), 230242. [21]

Aydınyer, Y. (2010). Proje tabanl öğrenmenin farklı bilişsel stillere sahip 7. sını f̈̆grencelerin geometri bilgi seviyesi, tutum ve aktif öğrenme stratejileri ve öğrenmenin değgerine etkisi (Basılmamış doktora tezi). ODTÜ, Ankara. [22]

Bal, A. B. (2012). Öğretmen adaylarının matematik dersinde proje görevi hazırlama sürecine ilişkin görüşleri. Journal of the Cukurova University Institute of Social Sciences, 21(2), 281299. [23]

Baran, M. ve Maskan, A. (2009). Proje tabanlı öğrenme modelinin fizik öğretmenliği ikinci sınıf öğrencilerinin elektrostatiğe yönelik tutumlarına etkisi. Dicle Üniversitesi Ziya Gökalp Ĕ̆itim Fakültesi Dergisi, 12, 41-52. [24]

Baş, G. (2011). Investigating the effects of project-based learning on students' academic achievement and attitudes towards english lesson. TOJNED : The Online Journal Of New Horizons In Education, 1(4), 1-15. [25]

Başbay, A. (2006). Basamaklı öğretim programıla desteklenmiş proje tabanlı öğrenmenin sürece, öğrenen ve öğretmen görüşlerine etkisi (Basılmamış doktora tezi). Hacettepe Üniversitesi, Ankara. [26]

Başer, D., Özden, M. Y. ve Karaarslan, H. (2017). Collaborative project-based learning: An integrative science and technological education project. Research in Science $\mathcal{E}$ Technological Education, 35(2), 131-148. [27]

Baysura, O.D., Altun, S. ve Yücel-Toy, B. (2015). Perceptions of teacher candidates regarding project-based learning. Eurasian Journal of Educational Research, 62, 15-36. [28]

Bell, S. (2010). Project based learning for the 21st century: Skills for the future. Clearing House, 83, 39-43. 
Benzer, E. (2010). Proje tabanl öğrenme yaklaşımıyla hazırlanan çevre eğitimi dersinin fen bilgisi ögretmen adaylarının çevre okuryazarlı̆̆ına etkisi (Basılmamış doktora tezi). Marmara Üniversitesi, İstanbul. [29]

Bilgü, H. (2008). İlköğretim sosyal bilgiler dersinde proje tabanlı öğrenme yönteminin öğrenci başarısına etkilerine ilişkin bir araştırma (Basılmamış yüksek lisans tezi). Dicle Üniversitesi, Diyarbakır. [30]

Binkley, M., Estad, O., Herman, J., Raizen, S., Ripley, M., MillerRicci, M., \& Rumble, M. (2012). Defining Twenty-First Century Skills. In P. Griffin, B. McGaw, \& E. Care (Eds.), Assessment and Teaching of 21st Century Skills (pp. 17-66). Dordrecht: Springer.

Birinci, E. (2008). Materyal tasarımı ve geliştirilmesinde proje tabanl öğrenmenin kullanılmasının öğretmen adaylarının eleştirel düşünme, yaratıcı düşünme ve bilimsel süreç becerilerine etkisi (Basılmamış yüksek lisans tezi). Zonguldak Karaelmas Üniversitesi, Zonguldak. [31]

Blumenfeld, P. C., Soloway, E., Marx, R. W., Krajcik, J. S., Guzdial M., Palincsar, A. (1991). Motivating project-based learning: Sustaining the doing, supporting the learning, Educational Psychologist, 26(3-4), 369-398.

Bozlar, B. (2017). Proje tabanlı öğrenmenin 5.sınıf fen bilimleri dersinde öğrencilerin akademik başarı ve bilimsel süreç becerilerine etkisi (Basılmamış yüksek lisans tezi). Çukurova Üniversitesi, Adana. [32]

Brown, S. (2018). Best practices in 21st century learning environments: A study of two p21 exemplar schools (Doktora tezi), Brandman, California.

Börekci, C. (2018). Proje tabanlı öğrenme ile öğrenenlerin özdüzenleme ve üstbiliş becerilerinin desteklenmesi (Basılmamış doktora tezi). Balıkesir Üniversitesi, Balıkesir. [33]

Bülbül, Y. (2017). Proje tabanlı öğrenme yönteminin sosyal biloiler öğretmen adaylarmın çevresel vatandaşlık düzeylerine etkisinin değerlendirilmesi üzerine bir karma desen araştırması (Basılmamış doktora tezi). Marmara Üniversitesi, İstanbul. [34]

Cam, Ç. (2013). Genel Kimya dersinde proje tabanlı öğrenme yönteminin öğrenci başarısına etkisi (Basılmamış yüksek lisans tezi). Dokuz Eylül Üniversitesi, İzmir. [35]

Canoğlu, M. (2007). Okul öncesi eğitim kurumlarına devam eden 6 yaş grubu çocuklarda proje tabanlı öğrenmenin sezgisel matematik becerilerine etkisi (Basılmamış yüksek lisans tezi). Abant İzzet Baysal Üniversitesi, Bolu. [36]

Cansoy, R. (2018). Uluslararası çerçevelere göre 21.yüzyıl becerileri ve eğitim sisteminde kazandırılması. Insan ve Toplum Bilimleri Araştırmaları Dergisi, 7(4), 3112-3134.

Cömert, G. G. (2014). Proje tabanlı öğrenmeye dayalı öğretim metodunun öğrencilerinin insan dolaşım sistemi kavramların anlamalarına ve biyoloji dersine karşı tutumlarına etkisi (Basılmamış doktora tezi). Orta Doğu Teknik Üniversitesi, Ankara. [37]

Çakallığlu, S. N. (2008). Proje tabanlı öğrenme yaklaşımına dayalı fen bilgisi öğretiminin akademik başarı ve tutuma etkisi (Basılmamış yüksek lisans tezi). Çukurova üniversitesi, Adana. [38]

Çakan, S. (2005). Proje tabanlı öğrenme yaklaşımının uygulandı̆̆ı 6. sınıf matematik dersine ilişkin öğrenci ve öğretmen görüşleri (bir eylem araştırması) (Basılmamış yüksek lisans tezi). Balıkesir Üniversitesi, Balıkesir. [39]

Çakıc1, Y. ve Türkmen Y. (2013). An investigation of the effect of project-based learning approach on children's achievement and attitude in science. TOJSAT: The Online Journal of Science and Technology, 3(2), 9-17. [40]

Çelik, H. Ç., İlhan, A. ve Gündüz, S. (2016). The evaluation of theses prepared on project-based learning in Turkey: A content analysis study. Ĕ̆itim Bilimleri Araştırma Dergisi, 6(2), 6174. 
Çeliker, H. D. (2012). Fen ve teknoloji dersi "güneş sistemi ve ötesi: Uzay bilmecesi" ünitesinde proje tabanlı öğrenme uygulamalarının öğrenci başarılarına, yaratıcı düşünmelerine, fen ve teknolojiye yönelik tutumlarına etkisi (Basılmamış doktora tezi). Dokuz Eylül Üniversitesi, İzmir. [41]

Çetin, O. ve Şengezer, B. (2013). Ortaokul Öğrencilerinin Proje Çalışmalarına İlişkin Görüşleri*. Ege Eğitim Dergisi, 14(1), 24-49. [42]

Çevik, M. (2018). Proje tabanlı (pjt) fen, teknoloji, mühendislik ve matematik (stem) eğitiminin, meslek lisesi öğrencilerinin akademik başarılarına ve mesleki ilgilerine etkisi. Pegem Ĕ̈itim ve Öğretim Dergisi, 8(2), 281-306. [43]

Çıbık, A. S., Aka, E. İ. Ve Kayacan, K. (2016). Genel fizik laboratuvarı-11 dersinde kullanılan proje tabanlı öğretim yönteminin öz-yeterlik, tutum ve başarıya etkisi. Kastamonu Eğitim Dergisi, 24(2), 511-534. [44]

Çıbık, A. S. (2011). Elektrik akımı konusunda yanlış kavramalar ve bunların giderilmesinde analojilerle desteklenmiş proje tabanl öğrenme yönteminin etkisi (Basılmamış doktora tezi). Gazi Üniversitesi, Ankara. [45]

Çıbık, A. S. (2006). Proje tabanlı öğrenme yaklaşımının fen bilgisi dersinde öğrencilerin mantıksal düşünme becerilerine ve tutumlarına etkisi (Basılmamış yüksek lisans tezi). Çukurova Üniversitesi, Adana. [46]

Çiftçi, S. (2006). Sosyal bilgiler öğretiminde proje tabanl öğrenmenin öğrencilerin akademik risk alma düzeylerine, problem çözme becerilerine, erişilerine, kahıcılığa ve tutumlarına etkisi (Basılmamış doktora tezi). Selçuk Üniversitesi, Konya. [47]

Çiftçi, F. (2011). İlköğretim din kültürü ve ahlak bilgisi dersinde proje tabanlı öğrenme yaklaşımı ve uygulama örnekleri (Basılmamış yüksek lisans tezi). Cumhuriyet Üniversitesi, Sivas. [48]

Çil, A. (2005). Kimya eğitiminde proje tabanl öğrenmenin incelenmesi ve öneriler (Basılmamış yüksek lisans tezi). Hacettepe Üniversitesi, Ankara. [49]

Çırak, D. (2006). Çocuklara İngilizce öğretiminde proje tabanlı öğrenmenin faydaları (Basılmamış yüksek lisans tezi). Selçuk Üniversitesi, Konya. [50]

Dağ, F. ve Durdu, L. (2012). Öğretmen adaylarının proje tabanlı öğrenme sürecine yönelik görüşleri. e-Journal of New World Sciences Academy, 7(1), 200-212. [51]

Dağhan, G., Nuhoğlu Kibar, P., Menzi Çetin, N., Telli, E. ve Akkoyunlu, B. (2017). Bilişim teknolojileri öğretmen adaylarının bakış açısından 21. Yüzyıl öğrenen ve öğretmen özellikleri. Eğitim Teknolojisi Kuram ve Uygulama, 7(2), 215-235.

Dede, C. (2010). Comparing frameworks for 21st century skills. In J. Bellanca \& R. Brandt (Eds.), 21st century skills: Rethinking how students learn (pp. 51-76). Bloomington, IN: Solution Tree Press.

Değirmenci, Ş. (2011). Fen ve teknoloji dersinde 'Canllar ve Enerji İlişkileri' ünitesinin öğretilmesinde proje tabanl öğrenmenin öğrenci başarısına etkisi (Basılmamış yüksek lisans tezi). Selçuk Üniversitesi, Konya. [52]

Demir, K. (2008). Bütünleştirilmiş öğretim programının işbirliğine dayalı ve proje tabanlı öğrenme yaklaşımıyla uygulanmasının etkililiği (Basılmamış doktora tezi). Hacettepe Üniversitesi, Ankara. [53]

Demir, T. (2013) Türkçe öğretimi dersinde proje tabanlı öğrenme yaklaşımı, Ana Dili Ĕ̆itimi Dergisi, 1(1), 53-76. [54]

Demiral, Ü. (2015). Proje tabanlı öğrenme yaklaşımı. İçinde G. Ekici (Ed.) Etkinlik örnekleriyle güncel öğrenme-öğretme yaklaşımları-II (s. 459-500). Ankara: Pegem Akademi Yayıncılık.

Demirhan, E., Köklükaya, A. N. ve Laçin Şimşek, C. (2017). Projeye dayalı öğrenmenin faydaları: Proje günlükleri örneği, Anadolu Öğretmen Dergisi, 1(2), 1-20. [55] 
Deveci, H. ve Eryılmaz, Ö. (2016). Öğretmen adaylarının sosyal sorumluluk projesine katılımlarına ilişkin görüşleri: Let's do it! Türkiye örneği, International Journal Of Eurasia Social Sciences, 7(25), 163-185. [56]

Dilli, R., Mamur, N., \& Sarıbaş, S. (2017). Kentin bellek mekânlarından imgeye: Görsel sanatlar eğitiminde proje tabanlı bir öğrenme yaklaşımı. Eğitimde Nitel Araştırmalar Dergisi Journal of Qualitative Research in Education, 5(3), 340-368. [57]

Dilşeker, Z. (2008). Fen ve teknoloji dersinde proje tabanl öğrenme yöntemi kullanımının ilköğretim 5. sinı öğrencilerinin fen ve teknoloji dersine yönelik tutumlarına, ders başarısına ve kavram yanılgılarının giderilmesine etkisi (Basılmamış yüksek lisans tezi). Dokuz Eylül Üniversitesi, İzmir. [58]

Doğan, K. (2008). Hücre konusundaki kavramların öğretilmesinde proje tabanlı öğrenmenin başarıya etkisi (Basılmamış yüksek lisans tezi). Afyon Kocatepe Üniversitesi, Afyonkarahisar. [59]

Doğay, G. (2010). Ekoloji ünitesinin öğrenilmesinde proje tabanl öğrenme yönteminin öğrenci başarısına etkisi (İstanbul ili örneği) (Basılmamış yüksek lisans tezi). Gazi Üniversitesi, Ankara. [60]

Duruhan, K. ve Şan, İ. (2013). Öğretmen adaylarının ÖTMG dersinde proje hazırlama sürecine ilişkin görüşlerinin incelenmesi. The Journal of Academic Social Science Studies: JASSS, 6(7), 379-399. [61]

Ekici, G., Abide, Ö. F., Canbolat, Y. ve Öztürk, A. (2017). 21.Yüzyıl becerilerine ait veri kaynaklarının analizi. Ĕ̆gitim ve Öğretim Araştırmaları Dergisi Journal of Research in Education and Teaching, 6(1), 124-134.

Ekiz, S. O. (2008). Fen ve teknoloji laboratuvarının proje tabanlı öğrenme yaklaşımı ile desteklenerek öğretiminin öğrenci başarısına, hatırda tutma seviyesine ve duyuşsal özelliklerine etkisinin araştırılması (Basılmamış yüksek lisans tezi). Muğla Üniversitesi, Muğla. [62]

Erdem, A. (2008). Proje tabanlı öğrenmenin ilköğretim yedinci sını öğrencilerinin bilgisayar dersi başarısına ve tutumuna etkisi (Basılmamış yüksek lisans tezi). Sakarya Üniversitesi, Sakarya. [63]

Erdem, M ve Akkoyunlu, B. (2002). İlköğretim sosyal bilgiler dersi kapsamında beşinci sınıf öğrencileriyle yürütülen ekiple proje tabanlı öğrenme üzerine bir çalışma. İlköğretim Online 1(1), 2-11. [64]

Erdemir, T. (2014). Uzaktan eğitimde bulut bilişim teknolojileri ile proje tabanlı öğrenme uygulaması (Basılmamış yüksek lisans tezi). Karadeniz Teknik Üniversitesi, Trabzon. [65]

Erdoğan, A. (2011). Sosyal bilgiler dersinde tarih konularını öğretiminde proje tabanlı öğrenme yaklaşımı (Basılmamış yüksek lisans tezi). Aksaray Üniversitesi, Aksaray. [66]

Erdoğan, G. (2007). Çevre eğitiminde küresel ısınmanın öğrenilmesinde proje tabanl öğrenmenin etkisi (Basılmamış yüksek lisans tezi). Zonguldak Karaelmas Üniversitesi, Zonguldak. [67]

Erdoğan, N. F. (2009). İlköğretim sosyal bilgiler öğretiminde proje tabanl öğrenmenin ders başarısı ve sını atmosferine etkisi (Basılmamış yüksek lisans tezi). Dokuz Eylül Üniversitesi, İzmir. [68]

Ersoy, A. (2007). İlköğretim beşinci sınıfta teknoloji destekli proje tabanlı öğrenme uygulamaları. Eskişehir: T.C. Anadolu Üniversitesi Eğitim Fakültesi Yayınları. No.101. [69]

Ersoy, R. (2013). Biyoloji eğitiminde proje tabanlı öğrenme yaklaşımının ortaöğretim öğrencilerinin üstbilişsel farkındalıklarına ve eleştirel düşünme eğilimlerine etkisi (Basılmamış doktora tezi). Gazi Üniversitesi, Ankara. [70] 
Eşsizoğlu, G. (2013). Sosyal bilgiler öğretiminde proje tabanlı öğrenmenin üstün zihin düzeyindeki öğrencilerin erişilerine, yaratıcı ve eleştirel düşünme düzeylerine etkisi (Basılmamış yüksek lisans tezi). İstanbul Üniversitesi, İstanbul. [71]

ETDME: Educational Technology Division Ministry of Education. (2006). Project-based learning handbook: Educating the millennial learner. Kuala Lumpur, Malaysia: Educational Technology Division Ministry of Education.

Fadel, C., Bialik, M., Trilling, B. (2015). Four-dimensional education: The competencies learners need to succeed. Boston (MA): Center for Curriculum Redesign.

Fatmawati, A. (2018). Students' perception of 21st century skills development through the implementation of project-based learning. Pedagogy Journal of English Language Teaching, 6(1), 37-46.

Fırat, Ş. (2008). İlköğretim 4. sını öğrencilerinin sosyal bilgiler dersine yönelik akademik başarıları üzerinde proje tabanlı öğrenme yaklaşımının etkisi (Basılmamış yüksek lisans tezi). İnönü Üniversitesi, Malatya. [72]

Girgin, D. (2009). Canlılar ve hayat ünitesinde proje tabanlı öğrenme yaklaşımının ilköğretim 5. sınıf öğrencilerinin akademik başarı ve tutumları üzerindeki etkisi (Basılmamış yüksek lisans tezi). Dokuz Eylül Üniversitesi, İzmir. [73]

Guo, S. ve Yang, Y. (2012). Project-based learning: An effective approach to link teacher professional development and students learning. Journal of Educational Technology Development and Exchange, 5(2), 41-56.

Gültekin, M. (2005). The effect of project based learning on learning outcomes in the 5 th grade social studies course in primary education. Educational Sciences: Theory and Practice, 5(2), 548-56. [74]

Gültekin, M. (2014). Okulöncesi öğretmenliği programı öğrencilerinin proje tabanlı öğrenmeye ilişkin görüşleri. Eskişehir Osmangazi Üniversitesi Sosyal Bilimler Dergisi, 7(2). [75]

Gültekin, Z. (2009). Fen eğitiminde proje tabanlı öğrenme uygulamalarının öğrencilerin bilimin doğasıyla ilgili görüşlerine, bilimsel süreç becerilerine ve tutumlarına etkisi (Basılmamış yüksek lisans tezi). Marmara Üniversitesi, İstanbul. [76]

Gündüz, M. (2014). İlköğretim 3.sınıf hayat bilgisi dersinde "sorumluluk" değerinin proje tabanlı öğrenme yaklaşımı ile öğretiminin akademik başarı ve tutuma etkisi (Basılmamış doktora tezi). Gazi Üniversitesi, Ankara. [77]

Günüç, S., Odabaşı, H.F. ve Kuzu, A. (2013). 21. Yüzyıl öğrenci özelliklerinin öğretmen adayları tarafından tanımlanması: Bir Twitter uygulaması. Eğitimde Kuram ve Uygulama, 9(4), 436- 455.

Güven, E. (2011). Çevre eğitiminde tahmin-gözlem-açıklama destekli proje tabanl öğrenme yönteminin farklı değişkenler üzerine etkisi ve yönteme ilişkin öğrenci görüşleri (Basılmamış doktora tezi). Gazi Üniversitesi, Ankara. [78]

Güven, İ. (2013). Fen ve teknoloji öğretmen adaylarının proje yönetimi deneyimlerinin değerlendirilmesi. Hacettepe Üniversitesi Eğitim Fakültesi Dergisi. Özel Sayı(1), 204-218. [79]

Hallermann, S., Larmer, J., \& Mergendoller, J. R. (2011). PBL in the elementary grades. Buck Institution for Education, Novato, CA.

Hasni, A., Bousadra, F., Belletête, V., Benabdallah, A., Nicole, M. C. ve Dumais, N. (2016). Trends in research on project-based science and technology teaching and learning at K-12 levels: A systematic review. Studies in Science Education, 52(2), 199-231. 
Işık, D. E. (2007). Hayat bilgisi öğretiminde proje tabanlı öğrenmenin akademik başarı, yaratıcı düşünme, kalıcılık, hayat bilgisi dersine karşı tutum düzeylerine etkisi (Basılmamış yüksek lisans tezi). Dokuz Eylül Üniversitesi, İzmir. [80]

İmer, N. (2008). İlköğretim fen ve teknoloji öğretiminde proje tabanlı öğrenme yaklaşımının öğrencilerin akademik başarı ve tutumuna etkisinin araştırılması (Basılmamış yüksek lisans tezi). Gazi Üniversitesi, Ankara. [81]

İncik, E. Y. (2017). İlkokul öğretmen ve öğrencilerinin proje tabanlı öğrenmeye ilişkin sorunların çözmede eylem araştırması: 4. sınıf Türkçe dersi kapsamında bir çalışma (Basılmamış doktora tezi). Mersin Üniversitesi, Mersin. [82]

İşçioğlu, E. (2010). Çevrimiçi proje tabanlı öğrenme ortamının öğrenci algısına ve başarısına göre değerlendirilmesi: Bir durum çalışması (Basılmamış doktora tezi). Ankara Üniversitesi, Ankara. [83]

Kalaycı, N. (2008). Yükseköğretimde proje tabanlı öğrenmeye ilişkin bir uygulama projeyi yöneten öğrenciler açısından analiz. Eğitim ve Bilim, 33(147), 85-105. [84]

Kalemkuş, F. ve Bulut Özek, M. (2021). 21. yüzyıl becerileri konusunda araştırma eğilimleri: 2000-2020 (ocak ayı). Manas Sosyal Araştırmalar Dergisi, 10(2), 878-900.

Kalyoncu, R. (2009). İlköğretim 8. sinif görsel sanatlar dersi kent projesi konusunda proje tabanl öğrenmeye dayal bir uygulama örneğ i (Basılmamış doktora tezi). Gazi Üniversitesi, Ankara. [85]

Kara, S. (2017). İlköğretim 6. sinıf görsel sanatlar dersinde Türk damgaları konusu ile milli değerlerin kazandırılmasında proje tabanlı öğrenmenin etkisi (Basılmamış doktora tezi). Gazi Üniversitesi, Ankara. [86]

Karaca, E. (2011). Pedagojik ajan destekli ortamda proje tabanlı öğrenme yaklaşımının insan ve bilgisayar etkileşimi dersi başarısına ve öğrenci tutumuna etkisi (Basılmamış yüksek lisans tezi). Bahçeşehir Üniversitesi, İstanbul. [87]

Karaçallı, S. (2011). İlköğretim 4. sinıf fen ve teknoloji dersinde proje tabanlı öğrenme yönteminin akademik başarıya, tutuma ve kalıcılı̆̆a etkisi (Basılmamış yüksek lisans tezi). Mehmet Akif Ersoy Üniversitesi, Burdur. [88]

Karagül, S. (2017). Türkçe eğitiminde proje tabanlı öğrenme yöntemiyle desteklenen basamaklı öğretim programının ögrencilerin okuma ve yazma becerilerine etkisi (Basılmamış doktora tezi). Ankara Üniversitesi, Ankara. [89]

Karakuş, M. (2017). Sosyal bilgiler dersinde proje tabanlı öğrenmenin öğrencilerin sorun çözme becerilerine, tutumlarına, akademik başarılarına ve öğrenmenin kalıcılığına etkisi*. Turkish Studies International Periodical for the Languages, Literature and History of Turkish or Turkic, 12(4), 239-254. [90]

Karayol, S. A. and Akaygün, S. (2017). The effects of project based learning on environmental literacy, 12th Conference of the European Science Education Research Association (ESERA), Dublin. [91]

Kaya, M. ve Oran, G. (2015). Proje tabanlı öğrenme yaklaşımı ve Türkçe öğretimine yönelik bir uygulama. Turkophone, 2(1), 17-25. [92]

Kayıran, T. (2009). Çoklu zekâ kuramı destekli proje tabanlı öğrenme yönteminin sosyal bilgiler dersinde akademik başarı, tutum ve kalıcılı̆̆a (Basılmamış yüksek lisans tezi). Çukurova Üniversitesi, Adana. [93]

Kaymakcı, S. ve Öztürk, T. (2011). Sosyal Bilgiler Öğretmenlerinin Proje Çalışmalarıyla İlgili Görüşleri. ODÜ Sosyal Bilimler Enstitüsü Sosyal Bilimler Araştırmaları Dergisi, 2(3), 103128. [94] 
Keser, K. (2008). Proje tabanlı öğrenme yaklaşımının fen bilgisi dersinde başarı, tutum ve kalıcı öğrenmeye etkisi (Basılmamış yüksek lisans tezi). Eskişehir Osmangazi Üniversitesi, Eskişehir. [95]

Keskin, E. (2011). Proje tabanl öğrenme yönteminin ilköğretim ikinci kademe öğrencilerinin başarı ve fen motivasyonlarına etkisinin incelenmesi (Basılmamış yüksek lisans tezi). Uludağ Üniversitesi, Bursa. [96]

Kılıç, M. (2009). Proje tabanlı öğrenmede web tabanlı araç geliştirilmesi ve kullanımına yönelik öğretmen ve öğrenci görüşleri (Basılmamış yüksek lisans tezi). Hacettepe Üniversitesi, Ankara. [97]

Kimsesiz, F., Dolgunsöz, E. ve Konca, M. Y. (2017). The effect of project based learning in teaching efl vocabulary to young learners of english: The case of pre-school children. International Journal of Languages' Education and Teaching, 5(4), 426-439. [98]

Kıyasoğlu, E. \& Çeviker Ay, Ş. (2020). Sınıf öğretmenlerinin 21. yüzyıl öğrenen ve öğreten becerilerinin incelenmesi . e-Kafkas Journal of Educational Research, 7(3), 240-261 .

Kızıltaş, N. T. (2017). Fen bilimleri dersi öğretiminde proje tabanlı öğrenme yönteminin uygulanmasına yönelik öğretmen ve öğrenci görüşleri: Muş örneği (Basılmamış yüksek lisans tezi). Muş Alparslan Üniversitesi, Muş. [99]

Koç, İ. (2008). Çoklu zekâ kuramına dayalı olarak gerçekleştirilen proje tabanlı öğrenmenin öğrencilerin 7. sınıf sosyal bilgiler dersindeki tutum ve erişilerine etkisi (Basılmamış yüksek lisans tezi). Selçuk Üniversitesi, Konya. [100]

Koçak, İ. (2008). Proje tabanlı öğrenme modelinin kimya eğitimi öğrencilerinin alkanlar konusunu anlamalarn ile kimya ve çevreye karşı tutumlarına olan etkisinin değerlendirilmesi (Basılmamış yüksek lisans tezi). Gazi Üniversitesi, Ankara. [101]

Koçoğlu, Ç. ve Köymen, Ü. (2003). Öğrencilerin hiperortam tasarımcısı olarak katıldığ1 öğrenme çevresinin yaratıcı düşünmeye etkisi. The Turkish Online Journal of Educational Technology - TOJET, 2(3), 127-136. [102]

Koparan, T. ve Güven, B. (2015). Proje tabanlı öğrenmenin öğrencilerin merkezi eğilim ve yayılım ölçülerine yönelik istatistiksel okuryazarlık seviyelerine etkisi. Kastamonu Ĕ̆itim Dergisi, 23(2), 773-796. [103]

Korkmaz, H. (2002). Fen eğitiminde proje tabanlı öğrenmenin yaratıcı düşünme, problem çözme ve akademik risk alma düzeylerine etkisi (Basılmamış doktora tezi). Hacettepe Üniversitesi, Ankara. [104]

Korkmaz, H. ve Kaptan, F. (2001). Fen eğitiminde proje tabanlı öğrenme yaklaşımı. Hacettepe Üniversitesi Ĕ̆itim Fakültesi Dergisi, (20), 193-200.

Köroğlu, Ü. M. (2011). Ingilizce öğretiminde proje tabanlı öğrenme ve portfolyo değerlendirme uygulamalarının lise öğrencilerinin başarısına etkisi (Basılmamış yüksek lisans tezi). Uludağ Üniversitesi, Bursa. [105]

Köse, M. (2010). İlköğretim 7. sinıf fen ve teknoloji dersi “'kuvvet ve hareket" ünitesinin öğretiminde proje tabanlı öğrenme yaklaşımının öğrencilerin başarı ve tutumlarına etkisi (Basılmamış yüksek lisans tezi). Selçuk Üniversitesi, Konya. [106]

Larmer, J., Mergendoller, J. R. ve Ross, D. (2015). Setting the standard for project based learning: A proven approach to rigorous classroom instruction. Alexandria, VA, USA: Association for Supervision and Curriculum Development.

Lin, C., Ma, J., Kuo, K.Y. and Chou, C.C. (2015). Examining the efficacy of project-based learning on cultivating the 21st century skills among high school students in a global context. i-manager's Journal on School Educational Technology, 11(1), 1-9. 
Memişoğlu, H. (2008). Sosyal bilgiler dersi öğretiminde proje tabanlı öğrenme yaklaşımı (Basılmamış doktora tezi). Gazi Üniversitesi, Ankara. [107]

Merriam, S. B. (2013). Nitel araştırma: Desen ve uygulama için bir rehber. S. Turan (Ed.), Ankara: Nobel Akademik Yayıncilık.

Meyer, K. and Wurdinger, S. (2016). Students' perceptions of life skill development in project based learning schools. Journal of Educational Issues, 2(1), 91-114.

Moylan, W. A. (2008). Learning by project: Developing essential 21st century skills using student team projects. The International Journal of Learning, 15(9), 287-292.

Musa, F., Mufti, N., Latiff, R. A., Amin, M. M. (2011). Project-based learning (PjBL): Inculcating soft skills in 21st century workplace. Procedia - Social and Behavioral Sciences, 59(2012), 565-573.

Nacaroğlu, O. (2015). Proje tabanl öğrenmenin fen bilgisi öğretmen adaylarmmn fotosentez konusundaki akademik başarısına etkisi (Basılmamış yüksek lisans tezi). İnönü üniversitesi, Malatya. [108]

Övez, M. G. (2007). Ortaöğretim 9. sinıf matematik öğretiminde proje tabanl öğretimin öğrenci başarısına etkisi (Basılmamış yüksek lisans tezi). Balıkesir Üniversitesi, Balıkesir. [109]

Özahioğlu, B. (2012). İlköğretim fen ve teknoloji dersinde proje tabanl öğrenmenin bilimsel süreç becerilerine, başarı ve tutum üzerine etkisi (Basılmamış yüksek lisans tezi). Çanakkale 18 Mart Üniversitesi, Çanakkale. [110]

Özarslan, M., Çetin, G:, Yıldırım, O. B., Salih, E. (2017). Üstün zekâlı ve yetenekli öğrenci ailelerinin bilsem biyoloji proje çalışmaları hakkındaki görüşleri. Abant İzet Baysal Üniversitesi Ĕ̆itim Fakültesi Dergisi, 17(3), 1411-1436. [111]

Özbayrak, Ö., Kılınç Alpat, S. ve Uyulgan, M. A. (2010). The investigation of the effect of project based learning on students' attitudes towards environment and laboratory. International Conference on New Trends in Education and Their Implications, 11-13 November, Antalya, Turkey. [112]

Özcan, R. (2007). Alg biyoteknolojisinde proje tabanl öğrenme yaklaşımının öğrencilerin akademik başarı, tutum ve görüşlerine etkisi (Basılmamış yüksek lisans tezi). Gazi Üniversitesi, Ankara. [113]

Özdemir, E. (2006). Proje tabanlı öğrenmenin öğrencilerin geometri başarılarına ve geometriye yönelik tutumlarına etkisinin araştırılması (Basılmamış yüksek lisans tezi). Orta Doğu Teknik Üniversitesi, Ankara. [114]

Özden, M., Aydın, M., Erdem, A. ve Ekmekçi, S. (2009). Öğretmenlerin proje tabanlı fen öğretimi konusunda görüşlerinin değerlendirilmesi*. Elektronik Sosyal Bilimler Dergisi, 8(30), 92-102. [115]

Özdener, N. ve Özçoban T. (2004), Bilgisayar eğitiminde çoklu zeka kuramına göre proje tabanlı öğrenme modelinin öğrenci başarısı üzerine etkisi. Kuram ve Uygulamada Ĕ̆itim Bilimleri, 4(1), 147-170. [116]

Özel, M. (2013). Proje tabanlı öğrenme yönteminin İlköğretim 2. kademe Fen ve Teknoloji derslerindeki uygulanmasının incelenmesi (Basılmamış yüksek lisans tezi). Trakya Üniversitesi, Edirne. [117]

Özensoy, A. U. (2017). Proje tabanlı öğrenme modelinin sosyal bilgiler dersinde başarıya etkisi. Uluslararası Türk Ĕgitim Bilimleri Dergisi, 9, 165-175. [118]

Özer, D. Z. (2011). Proje tabanlı öğrenmenin fen bilgisi öğretmen adaylarının biyoloji konularındaki başarılarına ve bilimsel süreç becerilerinin gelişimine etkisi (Basılmamış doktora tezi). Uludağ Üniversitesi, Bursa. [119] 
Özkarabacak, A. B. (2013). Aile katılımlı proje tabanlı öğrenme yaklaşımının 60-72 aylık çocukların farklı kültürlere bakış açısına etkisinin incelenmesi (Basılmamış yüksek lisans tezi). Marmara Üniversitesi, İstanbul. [120]

Özpınar, İ. ve Aydoğan Yenmez, A. (2017). Öğretmen adaylarının proje hazırlama süreçlerinin incelenmesi*. Turkish Studies International Periodical for the Languages, Literature and History of Turkish, 12(6),613-634. [121]

Öztürk, A. Ş. (2008). Illköğretim 7.sını öğrencilerine 'maddenin iç yapısına yolculuk' ünitesinin öğretiminde proje tabanl öğrenme yönteminin öğrencilerin başarı düzeyine etkisi (Basılmamış yüksek lisans tezi). Selçuk Üniversitesi, Konya. [122]

P21. (2009). P21 Framework definitions. 12.05.2018 tarihinde aşağıdaki adresten alınmıştır: http://www.p21.org/storage/documents/P21_Framework_Definitions.pdf

Polat, H. (2011). Proje tabanlı öğrenmede yönetim ve izleme bilgi sistemlerinin öğrenci başarısı ve tutumlarına etkisi (Basılmamış yüksek lisans tezi). Fırat Üniversitesi, Elazı̆̆. [123]

Ravitz, J., Hixson, N., English, M., \& Mergendoller, J. (2012). Using project based learning to teach 21st century skills: Findings from a statewide initiative. Paper presented at the American Educational Research Association Conference, Vancouver, Canada.

Saracaloğlu, A. S. ve Çelik, B. (2018). Web tasarımı ve programlama dersi öğretiminde proje tabanlı öğrenme yaklaşımı kullanımının öğrenci görüşlerine göre değerlendirilmesi. Kastamonu Ĕ̆gitim Dergisi, 26(2), 323-333. [124]

Savuran, D. (2007). Illköğretim yedinci sınıflarda proje tabanl matematik öğreniminin matematik başarısına tutuma ve kalıcılı̆̆a etkisi (Basılmamış yüksek lisans tezi). Balıkesir Üniversitesi, Balıkesir. [125]

Serttürk, M. (2008). Fen öğretiminde proje tabanl öğrenme yaklaşımının ilköğretim 7. sınıf öğrencilerinin fen başarısı ve tutumuna etkisi (Basılmamış yüksek lisans tezi). Sakarya Üniversitesi, Sakarya. [126]

Sezgin, F. (2008). Proje tabanlı öğrenme ve portfolyo değgerlendirmenin öğrenci başarısına ve tutum düzeylerine etkisi (Basılmamış yüksek lisans tezi). Zonguldak Karaelmas Üniversitesi, Zonguldak. [127]

Sözer, Y. (2017). Investigation of the project development process of the pupils who attend to the Tubitak research project contest: An action research. Inonu University Journal of the Faculty of Education, 18(2), 139-158. [128]

Sülün, Y., Ekiz, S. ve Sülün, A. (2012). Proje yarışmasının öğrencilerin fen ve teknoloji dersine olan tutumlarına etkisi ve öğretmen görüşleri. Erzincan Üniversitesi Eğitim Fakültesi Dergisi, 11(1), 75-94. [129]

Şahin, F., Güven, İ. ve Yurdatapan, M. (2013). Proje tabanlı eğitim uygulamalarının okul öncesi çocuklarında bilimsel süreç becerilerinin gelişimine etkisi. M. ̈̈. Atatürk Ĕ̆itim Fakültesi Ĕ̆itim Bilimleri Dergisi, 33, 157-176. [130]

Şahin, H. (2015). Ilköğretim sosyal bilgiler dersinde proje tabanlı öğrenme yönteminin uygulanabilirliğine yönelik öğretmen ve öğrenci tutumlarının değerlendirilmesi (Basılmamış yüksek lisans tezi). Ahi Evran Üniversitesi, Kırşehir. [131]

Şahin, M. (2009). İlköğretim fen ve teknoloji dersinde proje tabanlı öğrenme yönteminin uygulanması ile ilgili öğretmen ve öğrenci görüşleri (Basılmamış yüksek lisans tezi). Ondokuz Mayıs Üniversitesi, Samsun. [132]

Şahin, M. C. (2010). Eğitim Fakültesi öğrencilerinin yeni binyılın öğrencileri (OECD-New Millennium Learners) ölçütlerine göre değerlendirilmesi (Basılmamış doktora tezi). Anadolu Üniversitesi Eğitim Bilimleri Enstitüsü, Eskişehir. 
Şallı, D. (2011). Proje tabanlı öğrenme yaklaşımı ile 48-60 aylık çocuklara geri dönüşüm kavramının kazandırılması (Basılmamış yüksek lisans tezi). Marmara Üniversitesi, İstanbul. [133]

Tabuk, M. (2009). Proje tabanlı öğrenmede çoklu zeka yaklaşımının matematik öğrenme başarısına etkisi (Basılmamış doktora tezi). Marmara Üniversitesi, İstanbul. [134]

Taflı, T. (2010). Lise 1. sinıf biyoloji dersinde uygulanan proje tabanlı öğrenme yaklaşımının öğrencilerin başarısına etkisi (Basılmamış yüksek lisans tezi). Selçuk Üniversitesi, Konya. [135]

Talat, A. ve Chaudhry, H. F. (2014). The effect of pbl and 21st century skills on students' creativity and competitiveness in private schools. The Lahore Journal of Business, 2(2), 89-114.

Taşkın, Y. (2018). Proje tabanlı öğrenme yaklaşımının yazma becerisine ve yazma kaygısına etkisi (Basılmamış yüksek lisans tezi). Dumlupınar Üniversitesi, Kütahya. [136]

Tat, M. M. (2016). Öğretim tasarımı dersinde proje tabanlı öğretimin bazı değişkenlere etkisi (Basılmamış yüksek lisans tezi). Mustafa Kemal Üniversitesi, Hatay. [137]

Tatlı, Z. (2016). Proje geliştirme sürecine dair öğretmen görüşleri *. YYÜ Eğitim Fakültesi Dergisi (YYU Journal Of Education Faculty), 13(1), 631-656. [138]

Tekinarslan, E. (2004). Project-based distrubuted learning and adult learners. Turkish Online Journal of Distance Education-TOJDE, 5(2), 74-80. [139]

Tonbuloğlu, B., Aslan, D., Altun, S. ve Aydın, H. (2013). Proje tabanlı öğrenmenin öğrencilerin bilişüstü becerileri ve öz-yeterlik algıları ile proje ürünleri üzerindeki etkisi. Mustafa Kemal Üniversitesi Sosyal Bilimler Enstitüsü Dergisi, 10(23), 97-117. [140]

Toprak, E. (2007). Proje tabanlı öğrenme metodunun ilköğretim 5. sinı öğrencilerinin fen ve teknoloji dersindeki akademik başarısına etkisi (Basılmamış yüksek lisans tezi). Marmara Üniversitesi, İstanbul. [141]

Tosun, N. (2016). Böte bölümü öğrencilerinin proje tabanlı topluma hizmet uygulamaları dersine ilişkin görüşlerinin incelenmesi. Kastamonu Ĕ̆itim Dergisi, 22(3), 961-980. [142]

Trilling, B. and Fadel, C. (2009). 21st century skills: Learning for life in our times. Francisco: JosseyBass.

Tülüce, E. A. (2016). Proje tabanlı öğrenme yönteminin görsel sanatlar öğretmeni adaylarının akademik başarı ve tutumlarına etkisi (Basılmamış yüksek lisans tezi). Atatürk Üniversitesi, Erzurum. [143]

Türk, M. (2007). Proje tabanlı öğrenmenin yabancı dil kullanımında konuşma yeterliliğine etkisinin değerlendirilmesi (Basılmamış yüksek lisans tezi). Ankara Üniversitesi, Ankara. [144]

Uğraş, S, Keskin, H., Sipahi, N. ve Dursun, H. (2017). İlköğretim öğrencilerinde proje tabanlı mikroskobik canlı bilincinin oluşturulması. Karadeniz Sosyal Bilimler Dergisi, 9(2), 175188. [145]

Urhan, N. (2016). İşbirlikli proje tabanlı öğrenme sürecinde dijital belgesel üretiminin yansıtıcı düşünmeye katkısı (Basılmamış yüksek lisans tezi). Hacettepe Üniversitesi, Ankara. [146]

Uysal, M.P. (2018). Yazılım mühendisliğinde deneysel bir çalışma: Proje tabanlı ve proje destekli yöntemlerin ürün ve akademik başarıya etkileri. Pamukkale Üniversitesi Mühendislik Bilim Dergisi, 24(2), 226-237. [147]

Uzun, Ç. (2007). İlköğretim 4. ve 5. sinıf fen ve teknoloji dersi, "canlılar dünyasını gezelim tanıyalım" ünitesinde proje tabanlı öğrenmenin akademik başarı ve kalıcllı̆̆a etkisi (Basılmamış yüksek lisans tezi). Afyon Kocatepe Üniversitesi, Afyonkarahisar. [148]

Uzun, Y. (2007). Proje tabanlı öğrenme yaklaşımı ve ilköğretim din kültürü ve ahlak bilgisi derslerinde kullanılması (Basılmamış yüksek lisans tezi). Marmara Üniversitesi, İstanbul. [149] 
Wurdinger, S. ve Qureshi, M. (2015). Enhancing college students' life skills through project based learning. Innovative Higher Education, 40, 279-286.

Wurdinger, S. ve Rudolph, J. (2009). A different type of success: Teaching important life skills through project based learning. Improving Schools, 12(2), 115-129.

Yalçın, S. A., Turgut, Ü. ve Büyükkasap, E. (2009). Proje tabanlı öğretim yönteminin öğrencilerin elektrik konusu akademik başarılarına, fiziğe karşı tutumlarına ve bilimsel işlem becerilerine etkisinin incelenmesi. International Online Journal of Educational Sciences, 2009, 1(1), 81-105. [150]

Yalçınkaya, E. ve Karaca, A. (2018). Sosyal bilgiler öğretmen adaylarının sosyal projeye ilişkin görüşlerinin incelenmesi. 7. Uluslararası Sosyal Bilimler Eğitimi Sempozyumu, 11-13 Ekim, Kırşehir, Türkiye. [151]

Yaman, İ. (2014). EFL öğrencilerinin konuşma becerilerinin proje tabanl öğrenme yoluyla geliştirilmesine yönelik tutumları: Sınırsız öğrenme perspektifi (Basılmamış doktora tezi). Gazi Üniversitesi, Ankara. [152]

Yavuz, S. (2006). Proje tabanlı öğrenme modelinin kimya eğitimi öğrencilerinin çevre bilgisi ile çevreye karşı tutumlarına olan etkisinin değerlendirilmesi (Basılmamış doktora tezi). Hacettepe Üniversitesi, Ankara. [153]

Yıldırım, A. ve Şimşek, H. (2003). Sosyal bilimlerde nitel araştırma yöntemleri. Ankara: Seçkin Yayincilik.

Yiğit, N. ve Kirman Bilgin, A. (2013). Fen ve teknoloji dersi proje çalışmalarının sınıflandırılması ve bilimsel süreç becerileri kazanımları açısından incelenmesi. Türk Fen Ĕ̆itimi Dergisi, 10(3), 137-158. [154]

Yıldırım, H. (2011). Probleme dayah öğrenme ve proje tabanlı öğrenme yöntemlerinin ilköğretim öğrencilerinin başarılarına ve tutumlarına (Basılmamış yüksek lisans tezi). Selçuk Üniversitesi, Konya. [155]

Yıldırım, S. (2007). İlköğretim 4. sinıf sosyal bilgiler dersinde proje tabanlı öğrenme modelinin araştırma becerilerinin gerçekleşme düzeyine etkisi (Basılmamış yüksek lisans tezi). Marmara Üniversitesi, İstanbul. [156]

Yıldız, F. (2008). "Oran, orantı ve yüzdeler" ünitesinin proje tabanlı öğrenme ile öğrenilmesinin matematik dersindeki başarıya ve tutuma etkisi (Basılmamış yüksek lisans tezi). Marmara Üniversitesi, İstanbul. [157]

Yıldız, Z. (2012). Proje tabanlı öğrenme yaklaşımında ortaöğretim öğrencilerinin yaratıcı düşünme problem çözme ve akademik risk alma düzeylerine etkisi (Basılmamış yüksek lisans tezi). Gazi Üniversitesi, Ankara. [158]

Yılmaz, B. (2007). Öğretimde planlama ve değerlendirme dersinde uygulanan proje tabanlı öğrenme yaklaşımının öğrencilerin başarı ve tutumlarına etkisi (Basılmamış yüksek lisans tezi). Selçuk Üniversitesi, Konya. [159]

Yılmaz, F. N. (2015). Fen bilimleri öğretiminde proje tabanlı öğrenme yaklaşımının 6. sinı öğrenci başarısı ve bilimsel süreç becerilerine etkisi (Basılmamış yüksek lisans tezi). Pamukkale Üniversitesi, Denizli. [160]

Y1lmaz, M. (2017). İlköğretim öğrencilerinin proje tabanlı öğrenme modeline dayalı güvenli internet kullanımı uygulamalarının değerlendirilmesi: Hollandalı öğrencilerle bir eylem araştırması (Basılmamış yüksek lisans tezi). Marmara Üniversitesi, İstanbul. [161]

Y1lmaz, O. (2006). Illköğretim 7. sinıf sosyal bilgiler dersinde "proje tabanlı öğrenme" nin öğrenenlerin akademik başarıları, yaratıcılıkları ve tutumlarına etkisi (Basılmamış yüksek lisans tezi). Zonguldak Karaelmas Üniversitesi, Zonguldak. [162] 
Yılmaz, T. K. ve Çağıltay, K. (2016). Proje tabanlı çoklu ortam tasarımı sürecinde öğretim tasarımı becerilerinin gelişiminin araştırılması. The Turkish Online Journal of Design, Art and Communication - TOJDAC, 6(2), 244-260. [163]

Yucaşu, Ş. (2015). Proje tabanlı öğrenme yönteminin fen bilgisi öğretmen adaylarının çevre okuryazarlı̆̆ına etkisi (Basılmamış yüksek lisans tezi). Fırat Üniversitesi, Elazı̆̆g. [164]

Yurtluk, M. (2003). Proje tabanlı öğrenme yaklaşımının matematik dersi öğrenme süreci ve öğrenci tutumlarına etkisi (Basılmamış yüksek lisans tezi). Hacettepe Üniversitesi, Ankara. [165]

Yurttepe, S. (2007). İlköğretim fen bilgisi dersinde proje tabanlı öğrenmenin öğrenci başarısına etkisi (Basılmamış yüksek lisans tezi). Eskişehir Osmangazi Üniversitesi, Eskişehir. [166]

Yücel, H. S. (2012). Bilim ve sanat merkezlerinde sanat (Resim) alanında proje tabanlı öğrenme yaklaşımına göre hazırlanan görsel sanatlar eğitimi uygulamasının bir değerlendirmesi (Yasemin Karakaya Bilsem örneği) (Basılmamış doktora tezi). Gazi Üniversitesi, Ankara. [167]

Zengin, F. K. ve Yucasu, Ş. (2017). Proje tabanlı öğrenme yönteminin fen bilgisi öğretmen adaylarının çevreye yönelik bilgi ve davranış üzerine etkisi. International Journal of Eurasia Social Sciences, 8(28), 618-633. [168]

\section{EXTENDED SUMMARY}

\section{Introduction}

In the literature, there are studies showing that different 21st century skills can be acquired with PBL. In this way, students can achieve 21 Century skills as well as understanding the content knowledge. Thus, it contributes to the training of citizens who must be equipped with the conditions of the age, which is one of the main goals of education. However, in the literature, we could not come across any research on the frequency of 21st century skills that can be acquired by PBL with a collective evaluation both internationally and throughout our country. In this context, the 21st Century skills acquired through project-based learning are examined in the research. The main purpose of the research is to determine the 21st century skills acquired through project-based learning in line with the findings and results of the researches. According to main purpose of the research, following research questions were investigated:

1. Which research models have been used in these kind of studies?

2. Which study subjects do these kind of researches include?

3. What are the target groups of these kind of researches?

4. According to research findings, what is the acquisition frequency of $21^{\text {st }}$ Century skills that can be acquired with PBL?

The results of the research have a value in making designs for the acquisition of different 21st century skills in PBL applications and offer different examples and experiences to educational institutions, experts and teachers. In this respect, it is thought that it may enable different researches and new designs related to acquisition of 21st century skills through PBL.

\section{Method}

This research, whose main purpose is to determine 21st century skills that can be acquired with PBL, has been designed as a qualitative research. In this research, the 21st century skills acquired with PBL were examined using document analysis. A total of 168 academic publications were studied, including 26 doctoral theses, 85 master theses, 54 articles and 3 papers in the scope of the research after 
the comprehensive literature review in YÖK Theses Center, DergiPark, TR DIZIN, Asos Index and Google Scholar.

\section{Findings}

This research conducted to determine the 21st century skills acquired through PBL has been examined in total 168 studies. In the scope of the research, experimental model and qualitative methods were used together in $64(38.1 \%)$ of these studies, only experimental model was used in $60(35.7 \%)$, and only qualitative method was used in $30(17.8 \%)$ of them, both quantitative and qualitative methods were used in $7(4.2 \%)$ of them, and quantitative method was used alone in $7(4.2 \%)$ of them.

The subject of Science and Technology was the most studied subject in the research with 62 (36.9\%). Subsequently, Computer-ICT 23 (13.7\%), Social Studies 21 (12.5\%) Mathematics $13(7.7 \%)$ and Environment $10(6 \%)$ are the subjects of study, respectively.

In these publications where 21st century skills are sought in PBL research, it can be said that the most frequent target group is secondary school with 68 (\%40.4), and undergraduate with 48 (\%28.6). Subsequently, it can be stated that primary school with 20 (\% 11.9) and high school with 19 (\%11.3) respectively. It can be expressed that the PBL studies for preschool students and adults are less frequent with $5(\% 3)$ and $2(\% 1.2)$ respectively. There is just one research $1(\% 0.6)$ for both graduate and associate degree programs with the least number.

In the research, the skills obtained from 19 different sources as a result of content analysis by Ekici et al. (2017, s.130) were taken into consideration in order to determine the 21st century skills acquired with PBL. Within the scope of the research, the most frequently acquired 21st century skills with PBL are respectively communication (103-\%61.3), collaboration (102-\%60.7), research (98-\%58.3), information literacy (92-\%54.8). Then productivity-efficiency (86-\%51.2), motivation (80-\%47.6), innovation-creativity (79-\%47), thinking skills (70-\%41.7), responsibility (65-\%38.7), and problem solving (57-\%33.9). Attitude development can be emphasized as an important feature that can be acquired through PBL with (53 -\%31.5) frequency and percentage value. It can be said that PBL has a positive effect on academic achievement with $(92-\% 54.8)$ frequency and percentage value. Within the scope of the research, cultural awareness has (3-\%1.8) and economic literacy has (2-\%1.2) frequency and percentage value. The rest of 21st century skills such as perseverance, health, accountability, character education, global-local citizenship, overcoming prejudices and self-evaluation have (1-\%0.6) frequency and percentage value.

\section{Results and Discussions}

Experimental model (124-73.8\%) was mostly preferred in PBL studies for 21st century skills acquisition in the scope of the research. When the studies were examined according to the study subjects, it was seen that the science-technology subject was the most common with 62 frequencies and (36.9\%) percentage value. The meta-analysis study conducted by Ayaz (2014) and Balemen (2016) was also for science-technology. The most important reason for this can be expressed as the sufficient number of researches conducted in this topic. Similar results about the study topic of this research were also pointed out by Demiray (2013), Guo \& Yang (2012) and Kaşarc1 (2013). It has been observed that 143 of 168 research topics $(85.1 \%)$ are compatible with 21 st century themes in the context of study subjects.

It can be said that the most common target groups are secondary school and undergraduate level in PBL researches in which 21st century skills are looking for. It can be said that PBL studies are carried out at primary and high school at middle level and for preschool and adults at low level. Similar 
results about the target group of this research were also pointed out by Ayaz (2014), Balemen (2016), Çelik et al. (2016), Demiray (2013) and Kaşarcı (2013). For the future, studies that aim to acquire 21st century skills with PBL in primary schools can be focused on.

It is seen that the most frequently acquired 21st Century skills with PBL are communication, collaboration, research and information literacy, respectively. Then it can be stated that productivityefficiency, motivation, innovation-creativity, thinking skills, responsibility, problem solving and permanent learning respectively.

In the research conducted by Talat and Chaudhry (2014), a positive relationship was found between PBL and 21st century skills. More than $80 \%$ of the private schools participating in this research are based on innovation-creativity, critical thinking, problem solving, communication, collaboration, information literacy, research and inquiry, media literacy, ICT literacy, flexibility and adaptability, entrepreneurship and self-control, productivity, leadership. They reported that gaining and responsibility skills is a part of their institutional policies. In the research conducted by Talat and Chaudhry (2014), a positive relationship was found between PBL and 21st century skills. More than $80 \%$ of the private schools participating in that research reported that acquisition of 21st century skills such as communication, collaboration, critical thinking, creativity etc. is a part of their institutional policies. Many researches supported the positive relationship between PBL and 21st century skills and also the results of the current research about acquisition of 21st century skills through PBL (Gou \& Yang, 2012; Hasni et al., 2016; Lin et al., 2015; Meyer \& Wurdinger, 2016; Musa et al., 2012; Ravitz et al., 2012; Wurdinger \& Qureshi, 2015; Wurdinger \& Rudolph, 2009).

Attitude development (53-31.5\%) can be emphasized as an important feature that can be acquired with PBL. This finding can be considered as a very important result in terms of education and learning for students and learners who do not have a positive attitude towards both subjects and activities. Considering that learning begins with sensory recording that being triggered by attitude elements such as motivation and willingness according to information processing theory, it can be said that PBL effect on attitude development is a very valuable acquisition for learning and education in this context. Besides, PBL is seen as a serious source for motivation with $(80-\% 47,6)$ frequency and percentage value according to current research. The studies conducted also support the finding for attitude development (Ayaz, 2014; Hasni et al., 2016; Kaşarc1, 2013; Yang, 2012).

In the near future, considering that all 21st century skills are important, it can be stated that it would be appropriate and meaningful to conduct new researches on skills that have been determined to be less acquired with PBL according to the current research. 